\title{
CFD Flow Dynamics over Model Scarps and Slopes
}

\author{
Patrick A. Hesp ${ }^{1}$ and Thomas A.G. Smyth ${ }^{1,2}$
}

${ }^{1}$ Beach and Dune Systems (BEADS) Laboratory, College of Science and Engineering, Flinders University, Bedford Park, Adelaide, South Australia 5041.

Patrick.Hesp@flinders.edu.au

${ }^{2}$ School of Applied Sciences, University of Huddersfield, Queensgate, Huddersfield HD1 3DH, UK

\section{$\underline{\text { Abstract }}$}

As sea level rises, and during storm and surge events, coastal dunes may become cliffed or scarped by wave action. Knowledge of wind flow over dune scarps, and as scarps fill, their subsequent various slopes, is an essential first step to understanding sediment transport pathways from the beach to the dunes. In this study, flow over scarps (also termed forward facing steps) is reviewed, and the flow over a vertical scarp $\left(90^{\circ}\right)$ and three slopes of $45^{\circ}, 24^{\circ}$ and $14^{\circ}$, all $2 \mathrm{~m}$ in height, is examined via CFD modelling. The flow over three $90^{\circ}$ scarps with heights of $1 \mathrm{~m}, 2 \mathrm{~m}$ and $4 \mathrm{~m}$, and over a $2 \mathrm{~m}$ high vertical $\left(90^{\circ}\right)$ scarp for three increasingly oblique incident winds is also studied. The extent of wind flow deceleration, separation and recirculation becomes smaller with decreased slope, with maximum flow separation and reverse vortex development occurring in the front of the vertical scarp. The extent of crest wind flow separation and recirculation is greatest for the scarp $(7.8 \mathrm{~m}$ in length), and is considerably less for the $45^{\circ}$ slope ( $2.4 \mathrm{~m}$ in length). As scarp height increases, 
so too does the spatial extent of turbulent wind flow, wind speed, and extent of the flow separation region. For cases where the scarp slope varied but height remained constant, the extent of the flow separation region was greatest when the scarp was vertical. Wind flow separation was dramatically reduced below a scarp slope of $45^{\circ}$. As incident wind direction became more oblique over a vertical scarp, wind speed undergoes significantly less deceleration, and helicoidal vortices replace roller vortices. Our results demonstrate how scarp morphology and wind direction are likely to influence transport pathways.

Keywords: Scarps, scarp (forward facing steps) flow, CFD, flow separation, slope aerodynamics

\section{Introduction}

Scarping or cliffing of coastal dunes, and particularly foredunes, is very common. Scarping is usually caused by wave action during high tides, storms, and/or storm surge (Carter and Stone, 1989; Carter et al., 1990; Hesp, 2002; Jarmalavicius et al., 2012; Karunarathna et al., 2018; Piscioneri et al., 2019). It may also occur as a result of stream action where, for example, streams migrate alongshore, or breakout from a landward dune area as washouts (Calliari; 1998; Hesp and Walker, 2013). In inland coastal dunescapes, and in Earth and planetary fluvial and aeolian environments, scarps and cliffs are also common (Cooke et al., 1993; Tsoar et al., 1996; Hesp and Smyth, 2016; Bullard and Nash, 2000). In addition, climbing dunes, dune ramps and clifftop dunes, and dunes in valleys and troughs occur throughout semi-arid and desert landscapes as well as in coastal environments (Evans, 1962; Brothers, 1954; Hesp, 2005; Tsoar, 1983; Pye and Tsoar, 1990; Hack, 1941; Billingsley, 1986; Tsoar and Blumberg, 1991; Lancaster and Tchakerian, 1996; Clemmensen et al., 1997; 
Xianwan et al., 1999; Bourke et al., 2004; Lorenz and Zimbelman, 2014) and their formation

49

50

51

52 is naturally related to the flow conditions prevailing upwind, across, and downwind of the underlying slopes and scarps. Despite this, there have been few studies of flow over coastal dune scarps, or scarps, escarpments and cliffs in other aeolian/desert environments. In the fluid dynamics literature, scarps or cliffs are commonly referred to as 'forward facing steps' (e.g. Lesieur et al., 2003; Abu-Mulaweh, 2005; Hattori and Nagano, 2010), but also occasionally bluff bodies or escarpments, and the following includes studies related to these features, as these are identical to features commonly termed scarps in the coastal, aeolian and engineering literature. In the following we use the term 'scarp' to refer to all vertical or nearvertical landform units.

Given that scarping and scarp processes will become more prevalent in coastal environments as sea level rises and beaches and dunes retreat or translate landwards (Davidson-Arnott, 2005; Castelle et al., 2015; Walker et al., 2017), it is vitally important to better understand wind flow and aerodynamics over scarps (also known as forward facing steps) of various heights (cf. van der Kindere and Ganapathisubramani, 2018) and various scarp fill slopes (Figure 1). In addition, an improved understanding of flow separation that typically occurs in flows upwind of and over escarpments and scarps (Prantl, 1904) is critical to the performance of many industrial and flight applications (e.g. Hucho and Sovran, 1993; Kourta et al., 2015; Rowcroft et al., 2015). Note that it is not the intention of this paper to review scarping and scarp filling processes (see e.g. Carter et al., 1990; Christensen, 2003; Aagaard et al., 2004; Christiansen and Davidson-Arnott, 2004; Suanez et al., 2012; Ollerhead et al., 2013; Castelle et al., 2015; Masselink et al., 2016; Robin et al, 2020). 


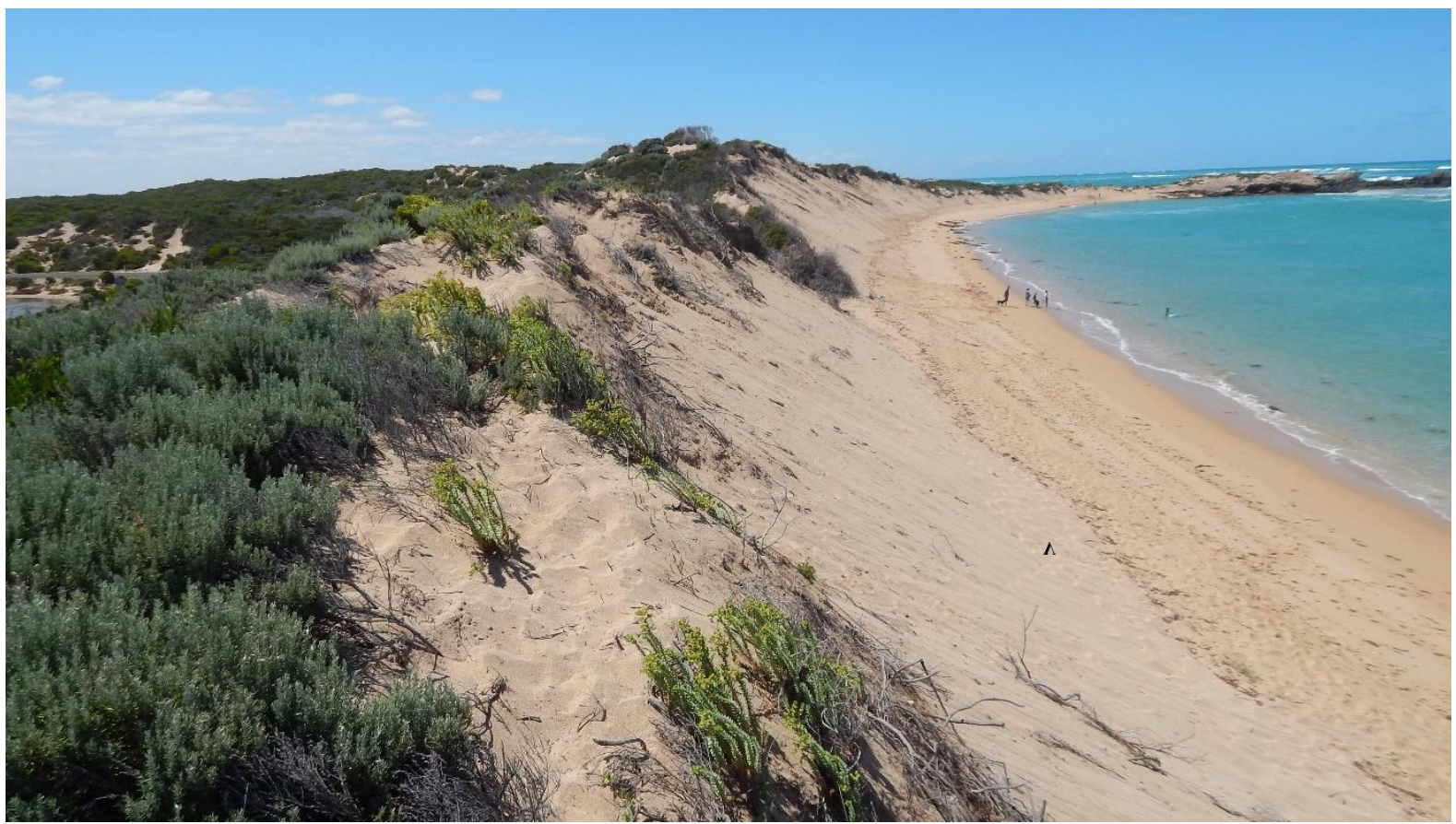

72 Fig 1a:- Scarp and slope with avalanche deposits on a erosional 15m high dune at Post Office

73 Rock, South Australia.

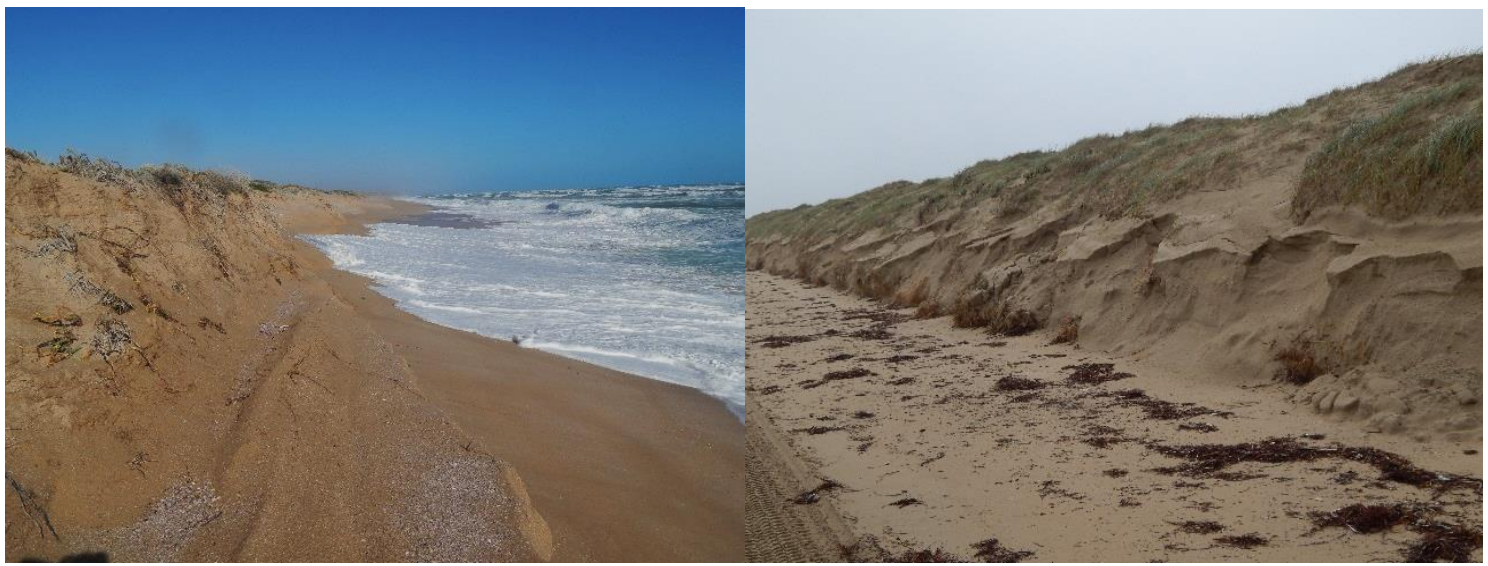

Figure 1b, 1c: Actively forming scarps on the Younghusband Peninsula, South Australia.

77 The flow structure approaching a scarp, cliff, escarpment, forward facing step, slope or transverse obstacle is primarily influenced by the slope gradient (Bowen and Lindley, 1977; Tsoar, 1983; Xianwan et al., 1999; Qian et al., 2011; Qian et al., 2012; Pires et al., 2015). At slopes less than $\sim 55^{\circ}$ to $60^{\circ}$, flow separation at the base of the escarpment or slope does not 
occur, and speedup upslope is common (Bowen and Lindley, 1977; Tsoar, 1983; Emeis et al., 1995; Mazumber and Sarkar, 2014). Above those slope gradients, the steeper the slope angle, the larger the upwind horizontal region occupied by a reversing vortex (Qian et al., 2012).

The flow separation region upwind of the scarp/slope is inherently turbulent and unsteady (Uruba and Knob, 2009). The degree of upwind turbulence and pressure increases with increasing slope (Xianwan et al., 1999), and the extent of flow separation depends on the Reynolds number (Hattori and Nagano, 2010). The upwind vertical speedup or velocity accelerations increase with decreasing slope below a gradient of $60^{\circ}$ (Bowen and Lindley, 1977; Tsoar, 1983; Qian et al., 2012). The position of the reversing vortex (or eddy) or flow separation region (envelope or bubble) upwind of the scarp, step or steep slope is also a function of slope angle such that the central position of the flow separation region shifts upwind and also higher vertically as slope angle increases (Qian et al., 2011). According to Pearson et al. (2013), the position of the upstream separation point lies between $-0.8 \mathrm{~h}$ and $1.2 h$ (where $h$ is scarp height). The height of the stagnation point at the top of the flow separation vortex is related to slope and increases as the slope increases (Tsoar, 1983).

The height of the scarp or forward facing step affects the flow structure. Largeau and Moriniere (2007) state that the height of the separation region, envelope, zone, or bubble (henceforth 'region') upwind of the step/scarp seems to be related to the height of the scarp/step $(h)$ such that the separation region height is $0.6-0.7 h$. Tsoar (1983) found that climbing dunes (essentially dunes that climb slopes) were formed at a slope angle of $50^{\circ}$ or less, while echo dunes (triangular-shaped dunes formed near the base of a scarp or steep slope and 'echoing' or mimicking the spanwise morphology of the scarp or slope) were formed at higher slope angles indicating a correspondence between the formation of reversing flow separation vortices at the toe of the steeper slopes and echo dune development. 
At or near the scarp or slope crest, a near-surface jet may form (Hsu, 1977; Arens et al., 1995;

Tsoar et al., 1996; Xianwan et al., 1999; Hesp et al., 2009; 2015; Jarmalavicius et al., 2012; above a vertical scarp compared to lower slopes (Yassin and Al-Harbi, 2013; Pires et al., 2015), and the extent of the flow separation region downwind of the scarp or escarpment/slope crest depends on incident flow velocity and scarp slope angle (Pires et al., 2011). The shear stress is highest on the scarp plateau downwind of the scarp crest (Hattori and Nagano, 2010), and is termed the turbulent shear region by Qian et al. (2011).

The turbulence intensity of both streamwise and transverse velocity fluctuations increases as step/scarp height increases, and the downwind length of the separation region increases with step height (Abu-Mulaweh, 2005). The average re-attachment length of the separation region on the scarp or step plateau or terrace depends on the incident velocity (Largeau and Moriniere, 2007), but is variable due to the flapping behaviour (low frequency fluctuations) or unsteady motion of the shear layer above the separation region (Largeau and Moriniere, 2007; Uruba and Knob 2009; Pearson et al., 2013). This flapping motion is related to the ejection of flow within the separated region (Sherry et al., 2010).

The flow structure will vary according to the aspect ratio $\left(\mathrm{L}^{*}\right)$ where $\mathrm{L}^{*}=L / h, L$ denoting the spanwise length of the scarp/step of height $h$. Where the spanwise length or $\mathrm{L}^{*}$ is small, horseshoe vortices dominate the upwind flow, whereas as L* increases, wavy horseshoe vortex structures form, and then with a further increase in $\mathrm{L}^{*}$, the horseshoe vortex disappears, branching occurs and smaller U vortices appear with defined alternating nodal and saddle points according to Chou and Chao (2000). While scarps vary alongshore in nature from a few metres to many kilometres along dune coasts and elsewhere, in this present study we do not consider short scarp walls or bluff bodies where horseshoe vortices are 
common (e.g. Hattori and Nagano, 2010), and where 'edge' effects are present and can be significant (cf. e.g. Hussein and Martinuzzi, 1996; Elkhoury, 2016).

In the geomorphology literature, while there are multiple papers describing flow over dunes (e.g. Arens et al., 1995; Walker and Nickling, 2002; Parsons et al., 2004; Liu et al., 2011; Jackson et al., 2011; Hesp et al., 2015; Bruno and Fransos, 2015; Smyth and Hesp, 2015; Hilton et al., 2016; Walker et al., 2017), apart from the pioneering studies of Hsu (1977), Tsoar (1983), Tsoar and Blumberg (1991), Tsoar et al. (1996), and Wiggs et al. (2002), there has been little modelling research conducted on wind flow relative to scarps, steep slopes been conducted at low Reynold's numbers, or with millimetre high step-heights.

In this study, wind flow was simulated via Computational Fluid Dynamics (CFD) in part to examine flow under fully turbulent Reynolds numbers typically experienced in the field, and further examine the flow dynamics for perpendicular and oblique incident flows over different scarp heights and various slope gradients, often difficult to achieve in the field. The aim was to examine three principal objectives, namely:

\section{Methods}


161

162 163

164 using the SIMPLE (Semi-Implicit Method for Pressure Linked Equations) algorithm to solve the Navier-Stokes equations (Patankar and Spalding, 1972). This method produced a steadystate, time averaged solution of flow within a computational domain. Turbulence was modelled using the RNG $k-\varepsilon$ method as it performs better than standard $\kappa-\varepsilon$ models in strongly separated flows (Kim et al., 1997; 2000, Maurizi, 2000). The RNG $k-\varepsilon$ method turbulence model has compared well with measured wind flow over a scarped foredune in the field (Hesp et al., 2015). A second order spatial discretisation scheme was employed to interpolate values between cell centres, and calculations were considered complete once the initial residual of each iteration was lower than $0.0001 \mathrm{~m} \mathrm{~s}^{-1}$ for $\mathrm{Ux}, \mathrm{Uy}$ and $\mathrm{Uz}$ (Figure 2).

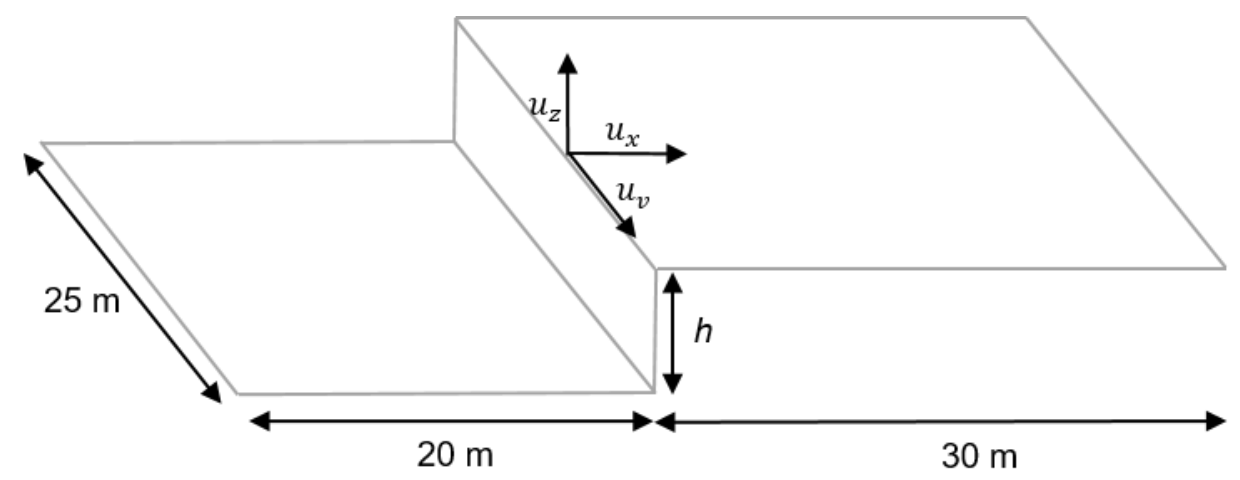

Figure 2. Schematic diagram of $90^{\circ}$ scarp surface within the computational domain.

In each simulation, vertical profiles of wind speed $(U)$, turbulent kinetic energy $(k)$ and energy dissipation $(\varepsilon)$ at the inlet boundary were defined assuming a constant shear velocity $\left(u_{*}\right)$ value with height using equations 1, 2 and 3 (Richards and Hoxey, 1993; Blocken et al., 2007):

$U(z)=\frac{u *}{\kappa} \ln \left(\frac{z+z_{0}}{z_{0}}\right)$ (eqn. 1)

$k(z)=\frac{u_{*}^{2}}{\sqrt{C_{\mu}}}$ (eqn. 2) 
$170 \quad \varepsilon(z)=\frac{u_{*}^{3}}{\kappa\left(z+z_{0}\right)}$

171 Where $z$ is the height above the surface, $\kappa$ is the von Kármán constant $(0.42), z_{0}$ is the 172 surface roughness length and $C_{\mu}$ a constant of 0.09 (Richards and Hoxey, 1993). In all 173 simulations wind flow was prescribed an incident speed of $20 \mathrm{~m} \mathrm{~s}^{-1}, 10 \mathrm{~m}$ above the surface $174\left(u_{*}=0.85 \mathrm{~m} \mathrm{~s}^{-1}\right)$ and $z_{0}$ a value of $0.0005 \mathrm{~m}$, equivalent to the roughness length of sand 175 (Bagnold, 1960). Figure 3 shows the modelled boundary layer $5 \mathrm{~m}$ downwind from the inlet 176 for both the $90^{\circ}$ cliff case and $14^{\circ}$ slope case.

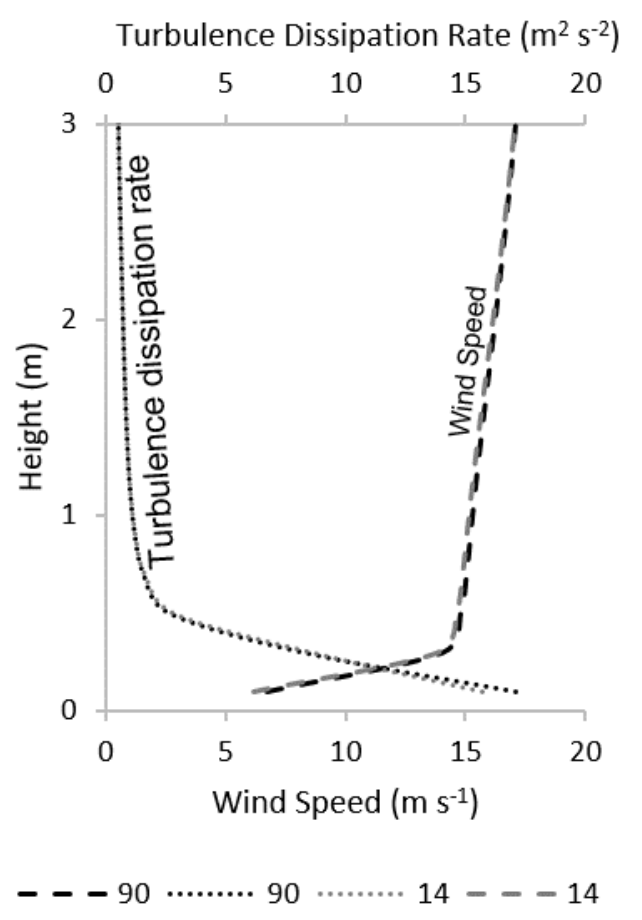

Figure 3. Wind speed $(\mathrm{U})$ and Turbulence dissipation rate $(\varepsilon)$ profiles measured $5 \mathrm{~m}$ downwind from the inlet of the computational domain for both the $90^{\circ}$ scarp and $14^{\circ}$ slope.

\subsection{Mesh independence study}

To ensure the results of each simulation were independent of mesh size, successively finer meshes (1.5 times finer than the preceding iteration) were run until the results converged (Figure 4). Convergence of wind speed occurred for meshes finer than $0.2 \mathrm{~m}$. All simulations generated therefore employed a uniform cell size of $0.2 \mathrm{~m}$. 


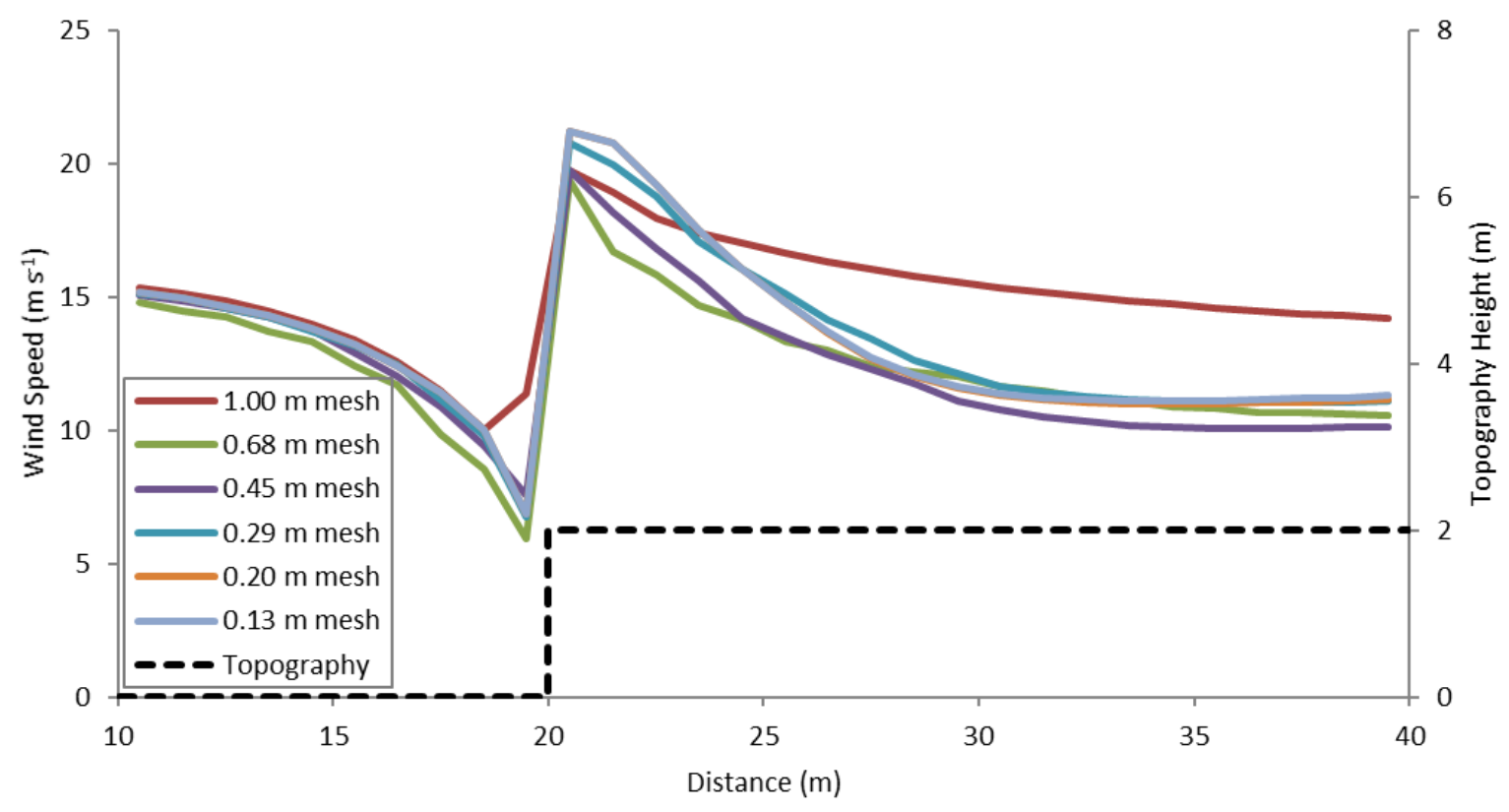

Figure 4. Wind speed $1.25 \mathrm{~m}$ above the surface over a $2 \mathrm{~m}$ scarp at increasing mesh resolutions. Results converged at a $0.2 \mathrm{~m}$ mesh resolution. The $0.2 \mathrm{~m}$ mesh line is located behind the $0.13 \mathrm{~m}$ mesh line. Incident wind speed was $20 \mathrm{~m} \mathrm{~s}^{-1} 10 \mathrm{~m}$ above the surface at the inlet.

\subsection{Comparison with laboratory measurements}

The wind flow modelling methodology in this investigation has been previously validated over a dune scarp in the field (Hesp et al., 2015). Wind flow modelled over a $2 \mathrm{~m}$ scarp with a freestream velocity of $20 \mathrm{~m} \mathrm{~s}^{-1}$ (Reynolds number $3.11 \times 10^{6}$ ) was qualitatively compared and verified with wind flow independently measured over a $40 \mathrm{~mm}$ high forward facing step in a wind tunnel with a freestream velocity of $40 \mathrm{~m} \mathrm{~s}^{-1}$ (Reynolds number $1.25 \times 10^{5}$ ) conducted by Largeau and Moriniere (2007) due to the close resemblance in experimental design (Figure 5). Streamwise flow relative to the inlet velocity demonstrates an analogous pattern of near-surface flow for both measured and modelled data. In both cases, flow velocity at the crest of the scarp is retarded approximately $1 \mathrm{~h}$ above the surface (where $\mathrm{h}$ is 

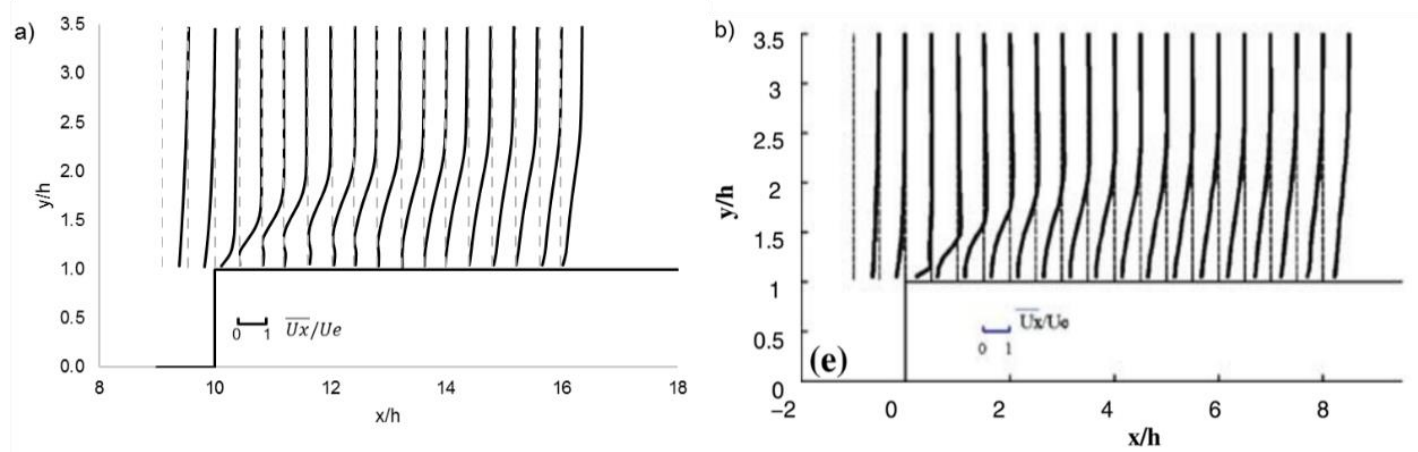

Figure 5 - (a) Modelled vertical profiles of streamwise flow over a $2 \mathrm{~m}$ scarp for a freestream velocity of $20 \mathrm{~m} \mathrm{~s}^{-1}$ (b) measured streamwise flow over a $40 \mathrm{~mm}$ forward facing step for a freestream velocity of $40 \mathrm{~m} \mathrm{~s}^{-1}$ (Image b adapted from Largeau and Moriniere, 2007). $\mathrm{y}=$ vertical coordinate, $\mathrm{x}=$ axial coordinate, $\mathrm{h}=$ step height $(\mathrm{m}), \overline{U x}=$ streamwise average velocity $\left(\mathrm{m} \mathrm{s}^{-1}\right)$ and $U e=$ external flow velocity $\left(\mathrm{m} \mathrm{s}^{-1}\right)$. In each case the solid black line represents relative streamwise average velocity and the dashed vertical line denotes a value of 0 streamwise average velocity.

\subsection{Slopes}

Wind flow was simulated over a vertical scarp and three slopes varying from a $90^{\circ}$ scarp to a 4:1 gradient slope $\left(14^{\circ}\right)$ replicating Bowen and Lindleys' (1977) investigation of four sharp edged escarpments (Figure 6). Scarps and scarp-filled slopes with a range of slopes from $14^{\circ}$ to $90^{\circ}$ are common on coastal dunes that have been recently scarped or in various stages of 

metres (Figure 1).

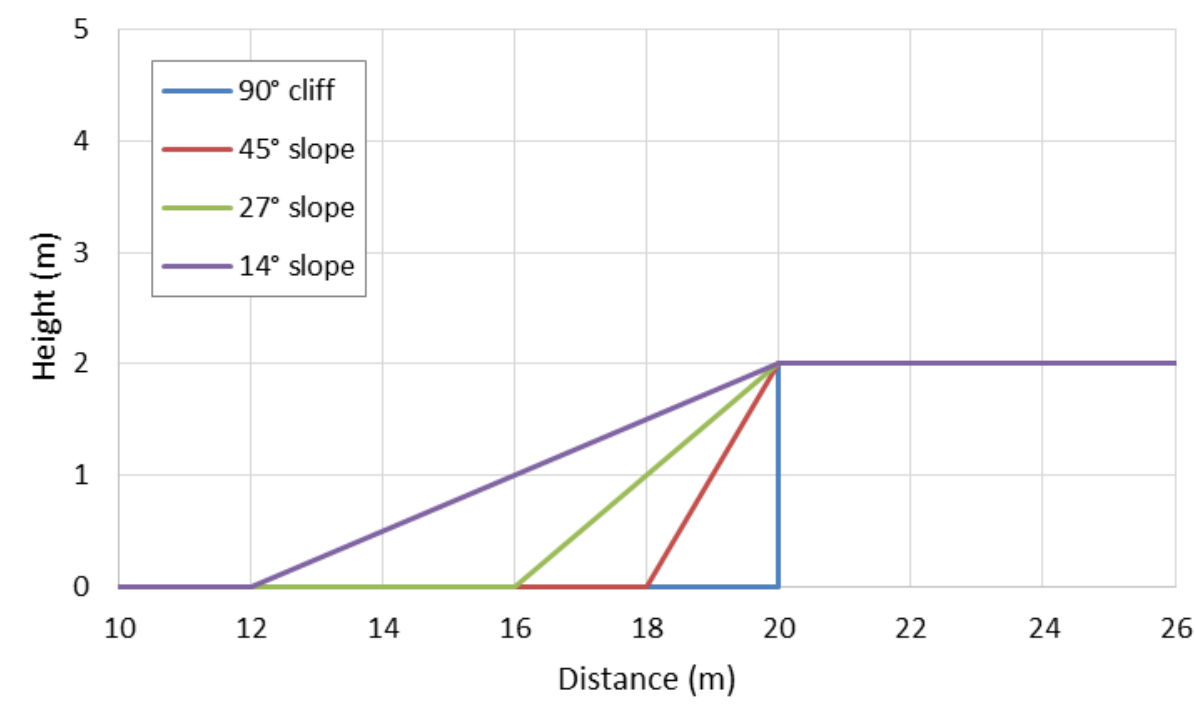

Figure 6. Topography of each scarp/slope tested. The crest of the scarp and various slopes is $2 \mathrm{~m}$ high above the upwind surface.

227 The position of the scarp/slope within the computational domain varied according to slope.

228 For the lowest gradient of slope tested $\left(14^{\circ}\right.$ slope $)$, the toe of the slope was located $12 \mathrm{~m}$ downwind from the inlet of the computational domain (Figure 6). In the case of the vertical scarp (at $90^{\circ}$ ), the toe of the scarp was positioned $20 \mathrm{~m}$ downwind from the inlet of the computational domain (Figure 6). In all cases, the crest of the scarp/slope was positioned 30 $m$ upwind from the outlet of the computational domain. This distance was chosen to ensure that any secondary flow patterns in the lee of the scarp could be adequately captured. For all simulations the height of the computational domain extended $24 \mathrm{~m}$ vertically, 5 times greater than the tallest scarp $(4 \mathrm{~m})$. To ensure a boundary height of $24 \mathrm{~m}$ was sufficiently high to avoid any significant blockage effects, an additional simulation was performed in which the height of the domain was increased to $80 \mathrm{~m}$. The percentage difference in velocity between a simulation with a boundary height of $24 \mathrm{~m}$ and a simulation with a boundary height of $80 \mathrm{~m}$ 
averaged $-0.08 \%$ across 30 points spaced at $1 \mathrm{~m}$ intervals along a transect perpendicular to the scarp crest. The lateral boundaries of the computational domain were defined as a symmetrical plane and a zero-gradient boundary condition was applied to the upper bounds

242 of the domain. The boundary condition at the surface of the model was defined using a wall

243 function in the same form as equation 1.

\section{Flow across the $2 \mathrm{~m}$ Scarp and Slopes}

245 Figure 7 illustrates the flow across the vertical $2 \mathrm{~m}$ scarp and three slopes $\left(45^{\circ}, 27^{\circ}\right.$ and $\left.14^{\circ}\right)$.

246 The flow structure upwind of the scarp and slopes varies according to slope gradient as found

247 in previous studies (e.g. Bowen and Lindley, 1977; Qian et al., 2011). The zone of upwind

248 flow deceleration is least for the lowest slope and increases with slope gradient. Both the

249 horizontal and vertical extents of the blue or lowest velocity zone increased with slope/scarp

250 gradient, forming a pronounced concave zone extending from the near scarp base to the scarp

251 crest in the case of the vertical scarp. Similar results were found by Yassin and Al-Harbi

252 (2013) using the FLUENT CFD code.

253 The rate of speedup upslope also increases with slope/scarp gradient, and is intense near, and

254 at the scarp crest region. The extent of wind flow deceleration, separation and recirculation

255 also becomes smaller with decreased slope, with maximum flow separation and reverse

256 vortex development occurring in the front of the vertical scarp (cf. Bowen and Lindley, 1977;

257 Tsoar, 1983; Qian et al., 2011). 


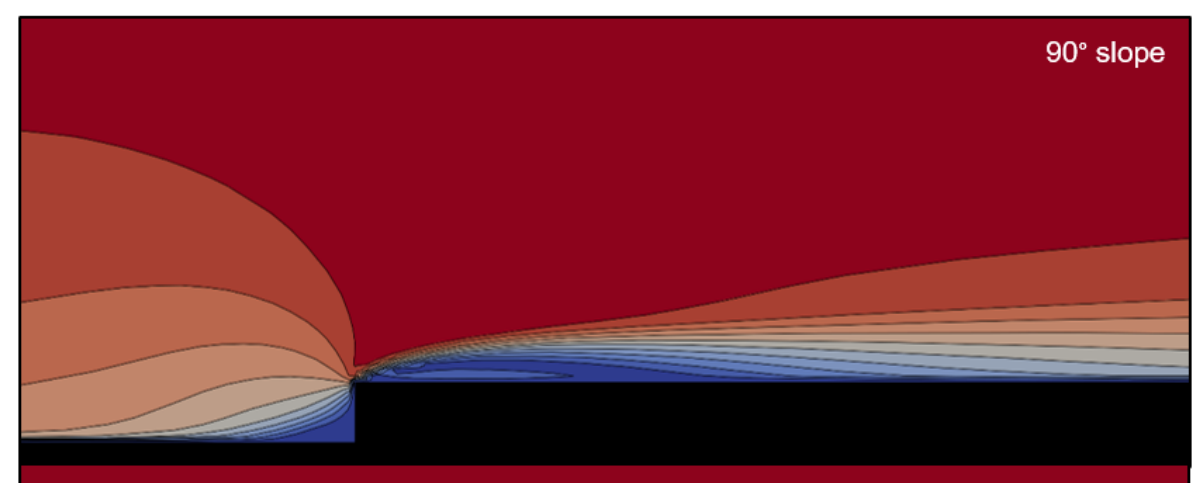

$45^{\circ}$ slope

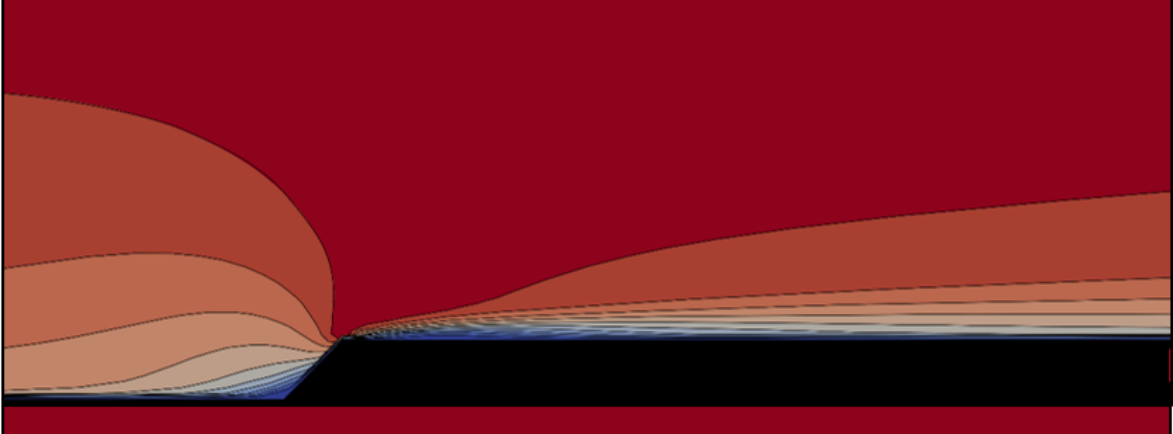

$27^{\circ}$ slope
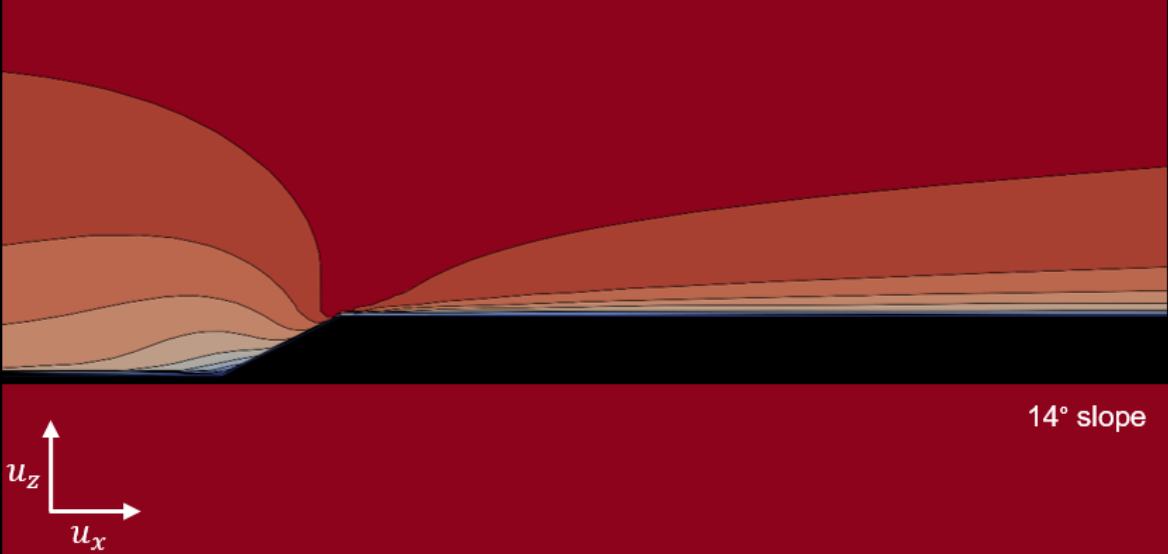

$14^{\circ}$ slope

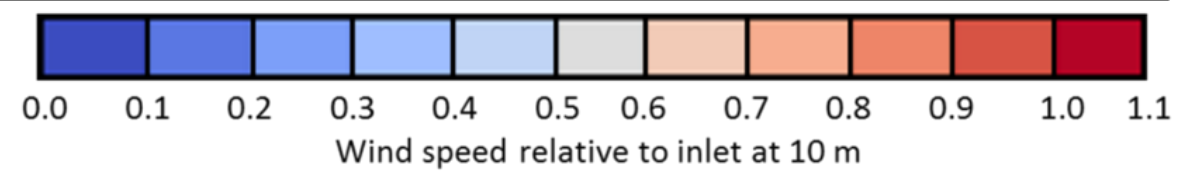

259 Figure 7. Two-dimensional slices through the centre of the computational domain. Wind

260 speed is relative to that $10 \mathrm{~m}$ above the surface at the inlet. All scarp or slope heights are $2 \mathrm{~m}$,

261 and the slopes range from $90^{\circ}, 45^{\circ}, 27^{\circ}$ to $14^{\circ}$. The zone of wind flow deceleration upwind of 
the escarpment becomes smaller with increased slope gradient, and the extent of wind flow deceleration becomes smaller with decreased slope. Wind speed at the crest of each escarpment reaches a similar maximum for all 4 cases.

Wind speed at the crest of each escarpment reaches a similar maximum for all 4 cases, similar to simulations over transverse dunes (Parsons et al., 2004). However, the zone of streamwise high speed flow extends further downwind beyond the scarp/slope crest, but is located higher above the surface of the scarp, as slope increases. The vertical depth of the lower velocity zone (primarily blue [or dark grey] in Figure 7) is greatest in the case of the vertical scarp $(1.5 \mathrm{~m})$ and much less $(0.7 \mathrm{~m})$ once the slopes are at $45^{\circ}$. The extent of crest wind flow separation and recirculation is greatest for the scarp (7.8 $\mathrm{m}$ in length), and is considerably less for the $45^{\circ}$ slope (2.4 $\mathrm{m}$ in length), as also found by Pires et al. (2011). The zone of upwind flow deceleration and lower wind speed (wind speed of less than 0.2 relative to the inlet at $10 \mathrm{~m}$ ) also becomes smaller from $2.8 \mathrm{~m}$ upwind of the scarp for the $90^{\circ}$ slope, to $1.4 \mathrm{~m}$ upwind of the $45^{\circ}$ slope.

Figure 8 illustrates streamlines for the same two dimensional slice through the centre of the computational domain but viewed at a $45^{\circ}$ angle to the scarp and slopes. The streamlines show that for the $90^{\circ}$ scarp, wind flow separation and reversing vortices form at the toe of the scarp and downwind of the scarp crest. No flow separation is apparent at the toe of the escarpment or downwind of the crest for the lower slopes ( $45^{\circ}$ and less). Note that the pattern of the velocity zones upwind of the scarp/slope crest comprising burnt orange through to salmon colours [or dark to very dark grey] are less asymmetric with a decrease in slope indicating a more uniform speedup upslope as slope gradient declines. 
285 Figure 9 provides a close-up view of the streamline patterns for the four escarpments. Only at 286 the vertical scarp do all the 0.6 to $1.0(60$ to $100 \%)$ velocity zones $\left(\mathrm{u} / \mathrm{u}_{10} \mathrm{~m}\right)$ meet in 287 conjunction at the scarp crest due to the pronounced, topographically forced acceleration. 

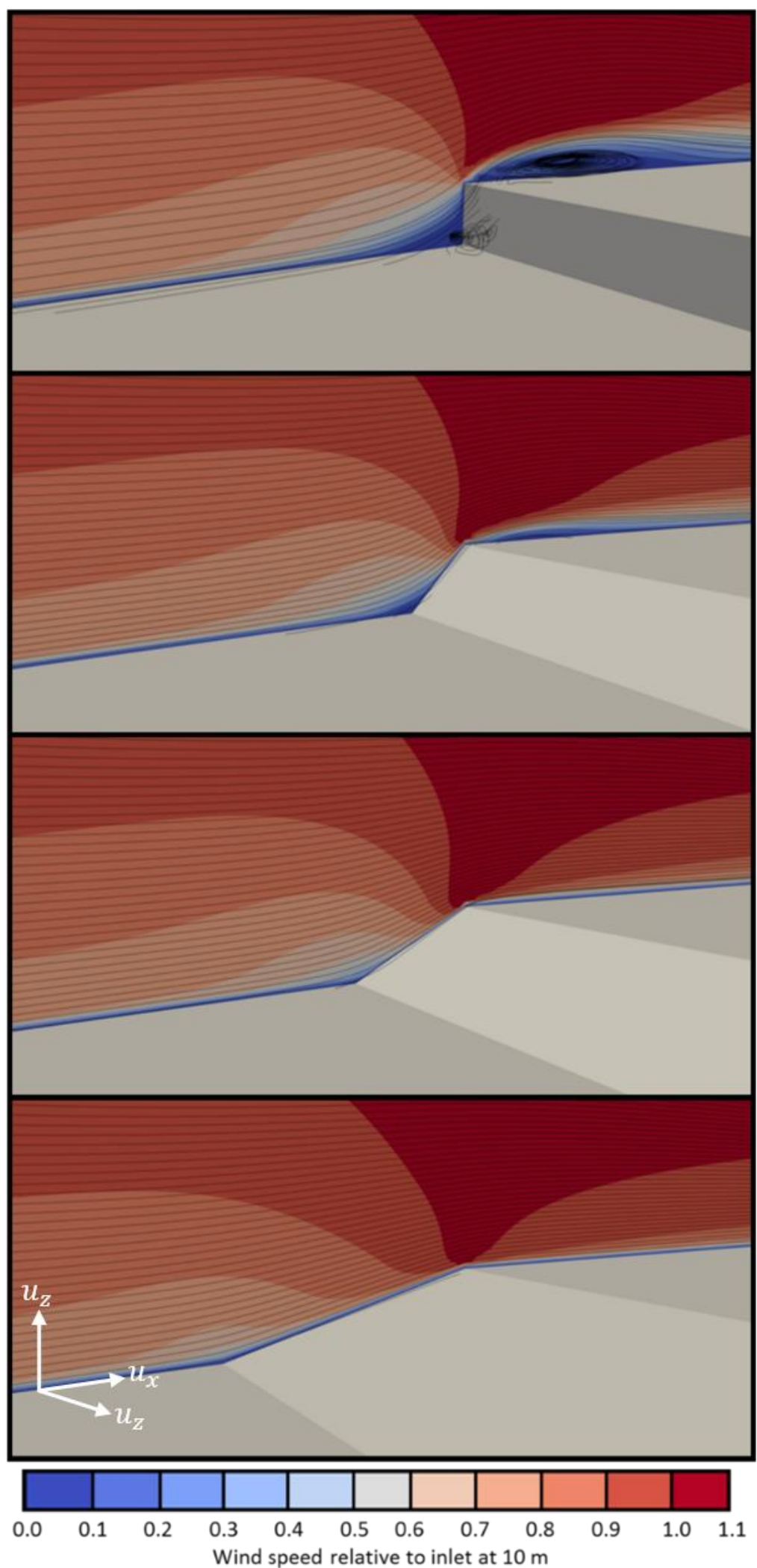

289 Figure 8. Two dimensional slice through the centre of the computational domain viewed at a $45^{\circ}$ angle to the scarp and slopes. Streamlines are seeded from the surface to the top of the 
computational domain every $0.2 \mathrm{~m}$. For the $90^{\circ}$ scarp, wind flow separates and forms a reversing vortex both at the toe of the escarpment and downwind of the crest.
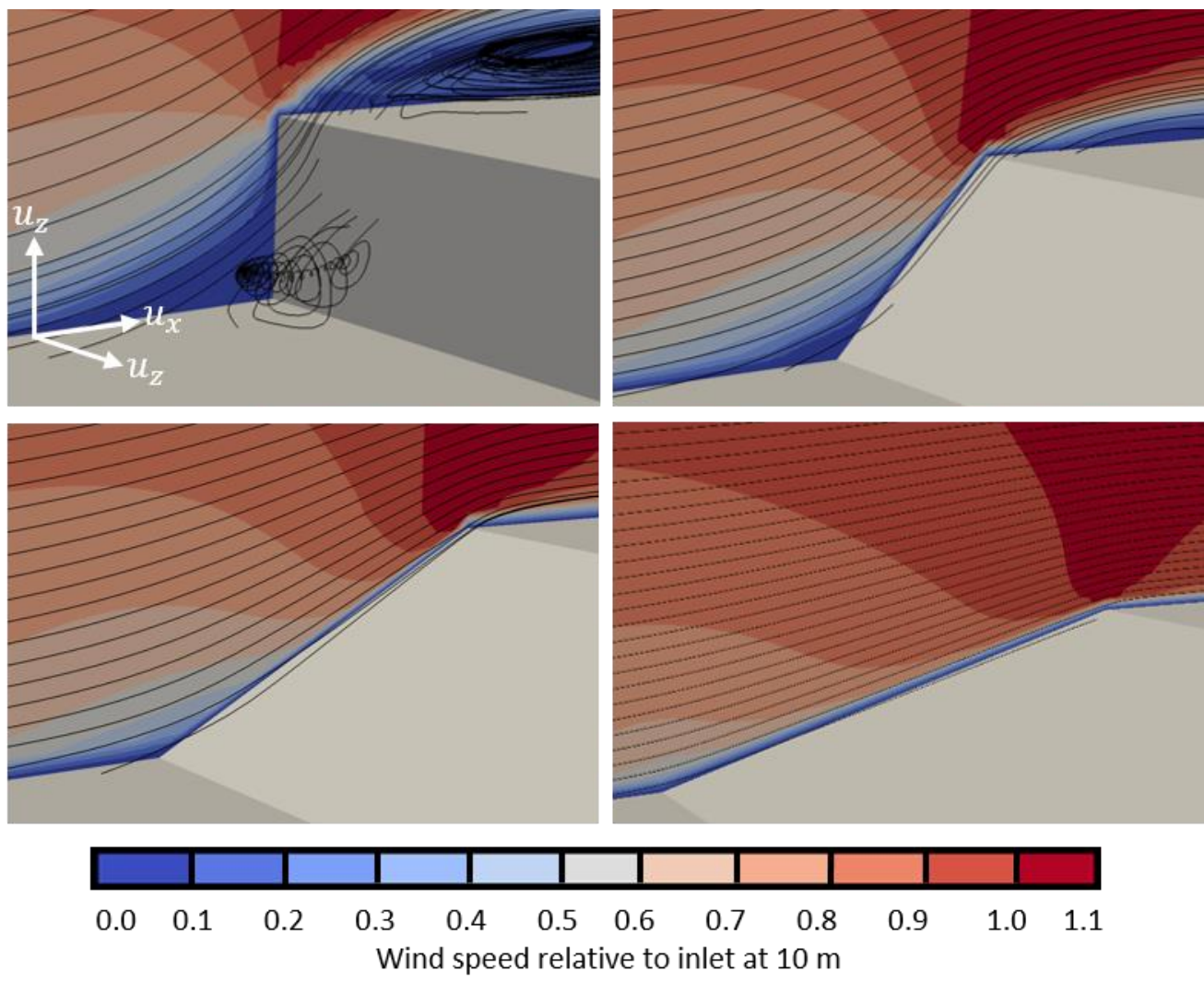

Figure 9. Two dimensional closeup slice through the centre of the computational domain viewed at a $45^{\circ}$ angle to the scarp $\left(90^{\circ}\right)$ and slopes $\left(45^{\circ}, 27^{\circ}, 14^{\circ}\right)$. Streamlines are seeded from the surface to the top of the computational domain every $0.2 \mathrm{~m}$. Flow separation occurs at the base and crest of the $90^{\circ}$ scarp. The pattern of speedup is more uniform as the slope gradient decreases.

Whereas with lower slopes, there is a more gradual increase in wind speed upslope such that by the lowest slope $\left(14^{\circ}\right)$, the 0.6 zone slope contact point occurs at mid-slope. In addition, the highest flow velocity zone occurs higher above the vertical scarp crest as a result of the 

region formed immediately at and downwind of the scarp crest. This observation is in close

305

306

307

308

309

310

311

312

313

314

315

316

317

318

319

320

321
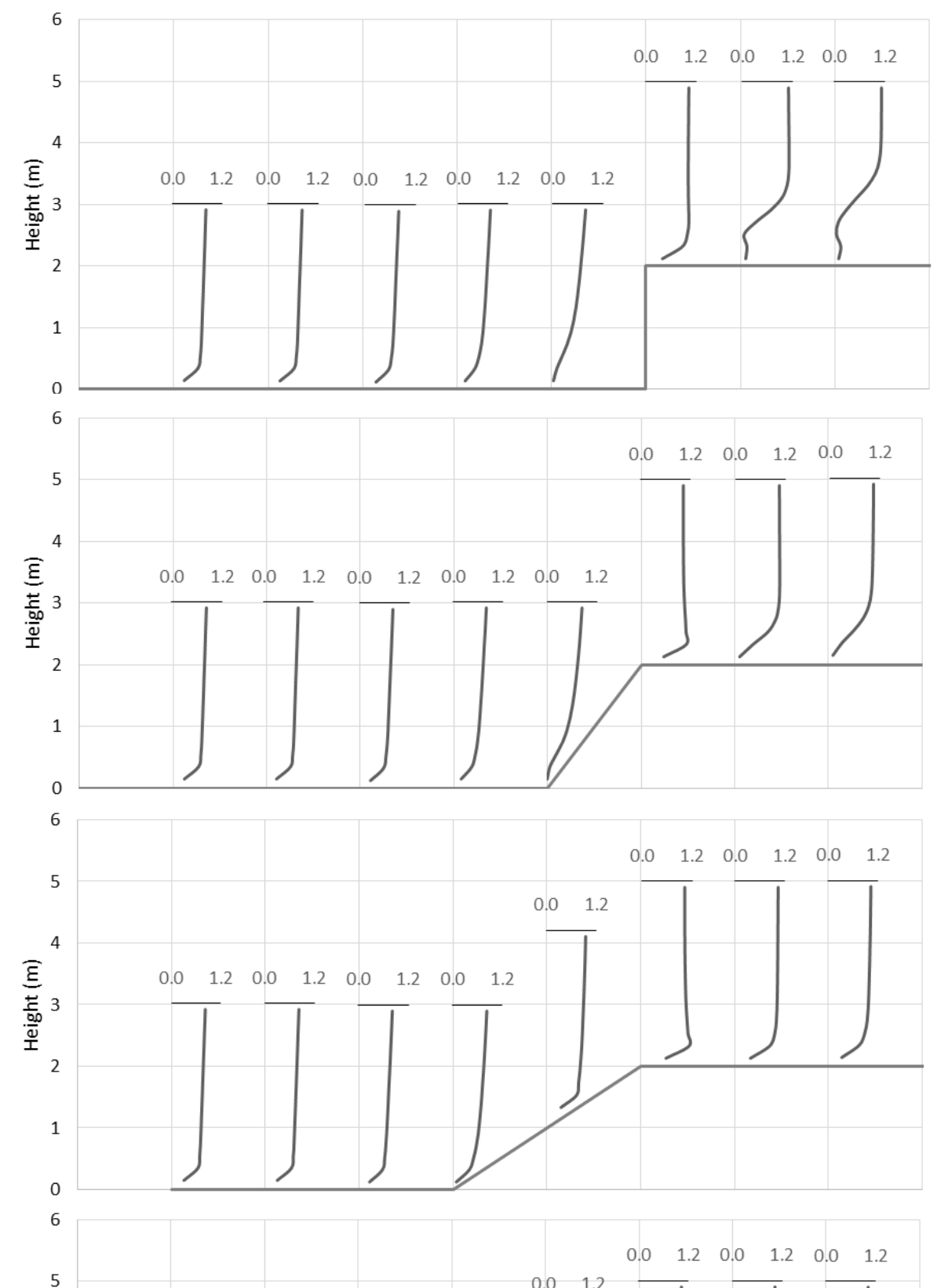

9

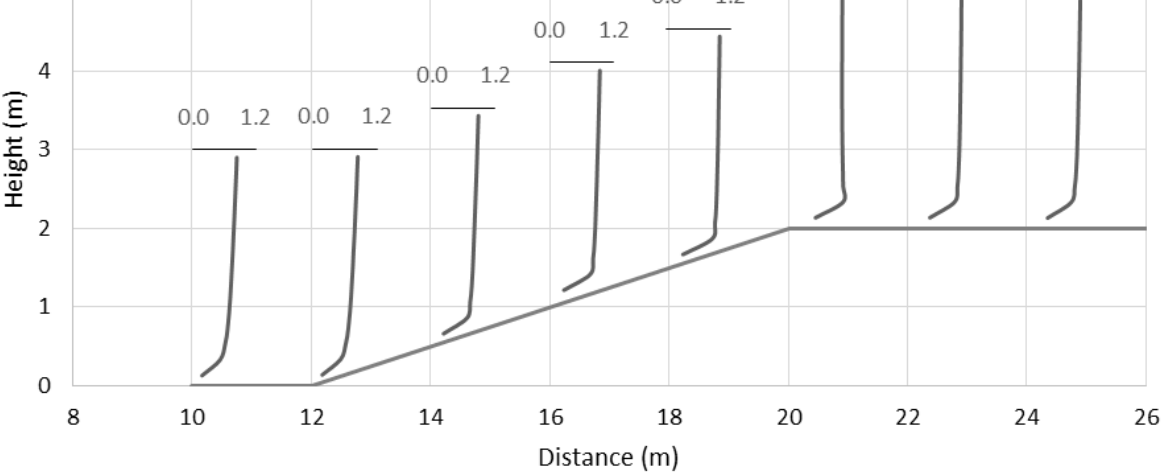


Figure 10. Vertical wind velocity profiles relative to wind flow $10 \mathrm{~m}$ above the surface at the inlet for the scarp $\left(90^{\circ}\right)$ and three slopes $\left(45^{\circ}, 27^{\circ}, 14^{\circ}\right)$. Velocity profiles were sampled every $2 \mathrm{~m}$. Wind flow deceleration at the toe of the scarp and in the lee of the scarp crest increases with increasing slope angle.

correspondence with the wind tunnel results of Bowen and Lindley (1977), and field studies of flow up a $28^{\circ}$ slope by Emeis et al (1995). As slope gradient declines, the zone of highest flow velocity changes in form from a sharp V-section to a bulbous shape, the near-surface apex of which is closer to the ground. This occurs because the speedup is more uniform upslope, and the degree of flow separation at the crest is significantly less to minor as the slope gradient decreases.

Velocity profiles across the four morphologies are illustrated in Figure 10. The velocity falls from low values to zero most rapidly upwind of the scarp base (or toe) for the vertical scarp. Piscioneri et al. (2019) also showed that the region adjacent to the base of a $1 \mathrm{~m}$ high vertical foredune scarp in the field displayed low to very low velocities. Significant velocity reduction also occurs at the base of the $45^{\circ}$ slope compared to the lower two slopes. A low level, nearsurface jet (a pronounced local high speed 'nose' in the velocity profile; see Hesp and Smyth, 2016) is formed at the crest of the three slopes as the flow is compressed and accelerates over the crest. A jet is commonly observed at, or just beyond a $1 \mathrm{~m}$ high scarp crest in the field (Hsu, 1977: Hesp et al., 2013; Piscioneri et al., 2019), but is not present on the vertical scarp in Figure 10 due to sampling spacing in the CFD modelling. Figure 9 demonstrates that the high speed zone above the crest of the vertical scarp is vertically higher, and positioned further downwind above the scarp than it is for the three slopes. This difference in the form 
and position of the high velocity zone, scarp versus slopes, strongly affects whether a jet is observed or not at the scarp crest in these $2 \mathrm{~m}$ spaced velocity profiles.

\section{Variation in Scarp Height and Flow Structure}

350

351

352

Figure 11 illustrates a two dimensional slice through the centre of the computational domain viewed at a $45^{\circ}$ angle to the scarp and slopes. The triangular zone of windward flow separation scales to the height of the scarp, increasing in horizontal and vertical extent as scarp height increases, and the flow separation vortex increases in magnitude and aerial extent with increasing scarp height. Flow separation is not apparent in this figure for the smallest $1 \mathrm{~m}$ high scarp possibly because the first streamline was seeded at $0.2 \mathrm{~m}$ height. In the field, as noted above, flow separation definitely occurs at the base of a $1 \mathrm{~m}$ scarp (Piscioneri, 2019). Subsequent data below on the TKE and pressure (Figure 12) indicates the likelihood of the presence of flow separation at the base of the $1 \mathrm{~m}$ high scarp.

Wind flow acceleration above the scarp increases with scarp height as may be observed by the velocity zone patterns near and above the scarp. In the case of the lowest (1m scarp), there is no dark orange [or dark grey] velocity zone apparent, whereas it appears as a prominent slice just landwards of, and above the crest in the case of the $2 \mathrm{~m}$ scarp. This zone is marked in the case of the $4 \mathrm{~m}$ scarp as a pronounced asymmetric V-shaped zone, and a red zone [very dark grey] of higher velocity also appears downwind and above the flow separation cavity or envelope. This progression of increasing velocity zones is due to the increased streamline convergence over the higher scarp. Furthermore, as one moves from lower to higher scarps this change in flow behaviour reflects the increasing dominance of the turbulent shear layer streaming off the scarp crest and being forced upwards by the amplified development of the separation vortex downwind of the scarp crest. 
Flow separation and the formation of a reverse vortex within a cavity or separation region occurs downwind of the scarp crest as noted by several authors (Qian et al., 2011; Hesp and
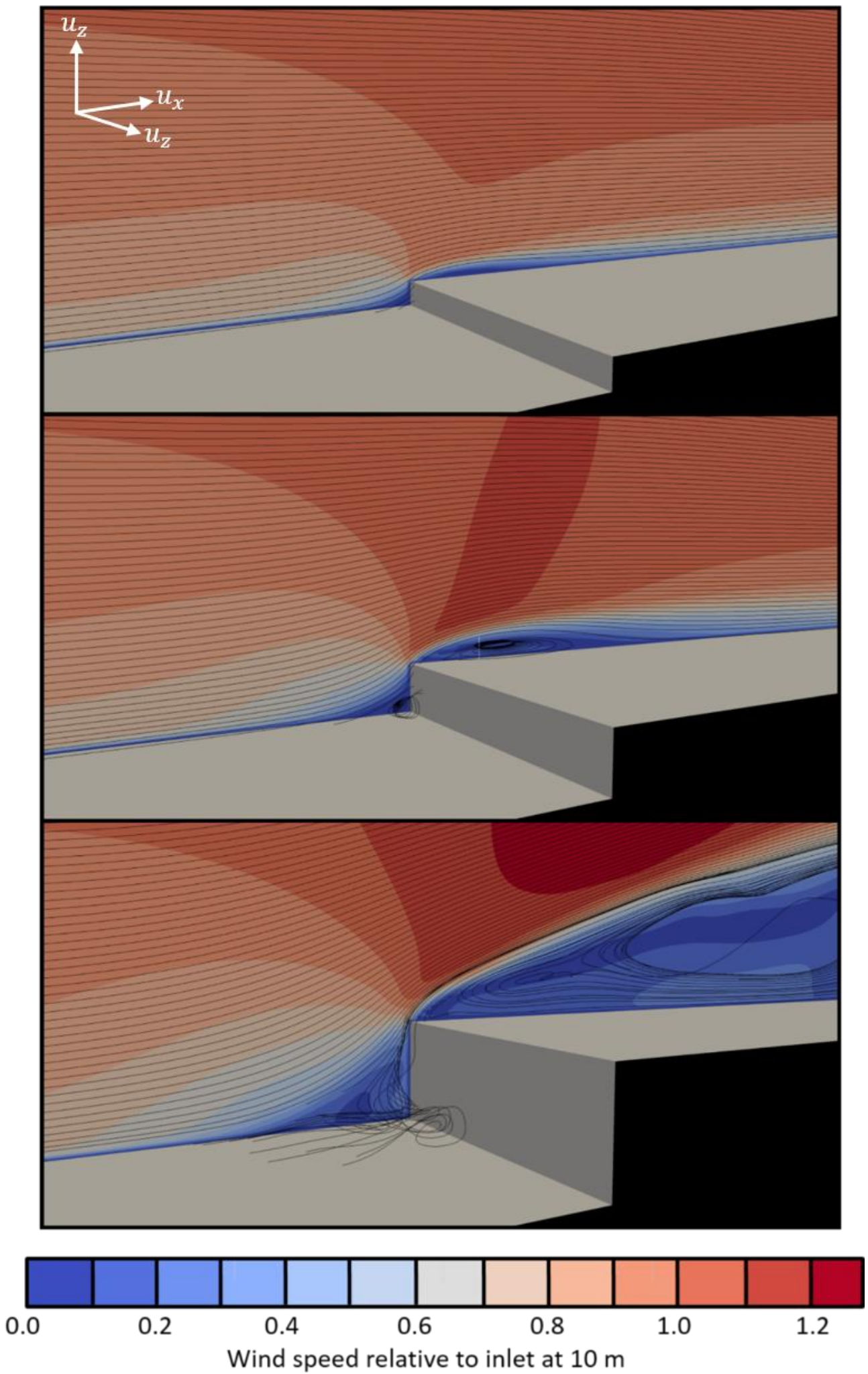
373 Figure 11. Two dimensional slice through the centre of the computational domain viewed at a $37445^{\circ}$ angle to the scarp, for three scarp heights (1, 2 and $4 \mathrm{~m}$ high). Streamlines are seeded 375 from the surface to the top of the computational domain every $0.2 \mathrm{~m}$. Flow separation 376 vortices are greatest at the base of the highest scarp, wind flow acceleration above the scarp

377 increases with scarp height, and the crest flow separation region expands with increasing 378 scarp height.

380 Smyth, 2016; Bauer et al., 2013; Pires et al., 2015; Shao and Agelin-Chaab, 2016). The 381 horizontal and vertical extent of the vortex increases as scarp height increases becoming higher and longer with increasing scarp height. The slope at the top of the separation region 383 also increases as scarp height increases presumably because as the scarp becomes higher, the 384 topographically accelerated flow immediately windward of the scarp must intensify and 385 proliferate in the vertical plane, and extends across the scarp crest at a higher approach angle. 

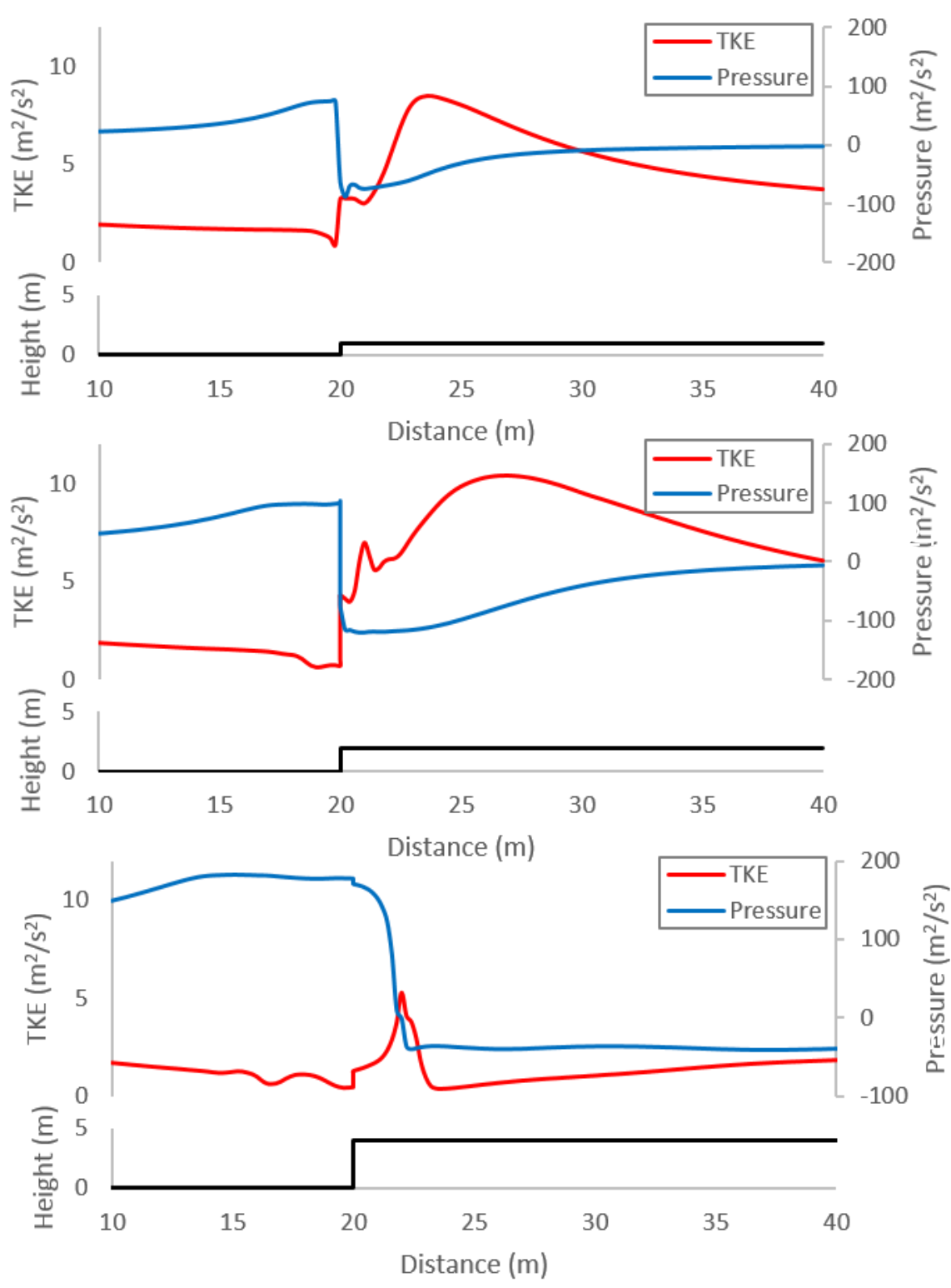

387 Figure 12. Turbulent Kinetic Energy (TKE) and Pressure calculated $0.25 \mathrm{~m}$ above the surface

388 along the centre of the computational domain for the 3 scarp heights $(1,2$ and $4 \mathrm{~m}$ high

389 respectively). Pressure upwind of the scarp increases, and extends further upwind with

390 increasing scarp height. Turbulent kinetic energy immediately downwind of the scarp crest

391 dramatically decreases for the $4 \mathrm{~m}$ tall scarp compared to the $1 \mathrm{~m}$ and $2 \mathrm{~m}$ high scarps. 
Figure 12 illustrates the turbulent kinetic energy (TKE) and pressure calculated at $0.25 \mathrm{~m}$ above the surface for the three scarp heights. TKE falls rapidly very near the base of the $1 \mathrm{~m}$ scarp. The TKE is somewhat lower upwind as scarp height increases, and is also more irregular or fluctuating for the $4 \mathrm{~m}$ scarp height. In concert with this, the zone of high pressure upwind of the scarp increases in extent as scarp height increases, and is significantly higher for the $4 \mathrm{~m}$ scarp $10 \mathrm{~m}$ upwind compared to the $1 \mathrm{~m}$ and $2 \mathrm{~m}$ scarps. Pressure at the 4 m scarp maintains high values a significant distance upwind of the scarp compared to the $1 \mathrm{~m}$ and $2 \mathrm{~m}$ scarps.

TKE falls dramatically at the scarp crest but the form of the decline varies according to scarp height, being vertical for the $1 \mathrm{~m}$ and $2 \mathrm{~m}$ scarps but curvilinear for the $4 \mathrm{~m}$ scarp. In the latter case, the TKE declines to a similar level as the other two scarps but extends around $3 \mathrm{~m}$ in horizontal extent in doing so, due to the greater development of turbulent eddies associated with the increased flow separation vortex formed over and downwind of the $4 \mathrm{~m}$ scarp crest.

The far greater development of a flow separation region downwind of the scarp crest in the case of the $4 \mathrm{~m}$ scarp compared to the $1 \mathrm{~m}$ and $2 \mathrm{~m}$ scarps has a significant effect on TKE and pressure. All three scarps show peaks of TKE at or immediately downwind of the scarp crest, although the development is most delayed for the $4 \mathrm{~m}$ scarp. The TKE is then convex asymmetric ( $1 \mathrm{~m}$ scarp), to slightly asymmetric ( $2 \mathrm{~m}$ scarp), and high for the $1 \mathrm{~m}$ and $2 \mathrm{~m}$ scarps, but sharply concave and low for the $4 \mathrm{~m}$ scarp. The pressure falls to similar levels downwind of the scarp crest for all cases, but again is delayed in reaching the lowest level for the $4 \mathrm{~m}$ scarp. The pressure recovers to near-neutral levels soonest in the case of the lowest 1 m scarp, followed by the $2 \mathrm{~m}$ scarp, but remains at negative pressures a considerable distance downwind in the $4 \mathrm{~m}$ scarp case, again presumably due to the marked development of the separation vortex and region for that scarp height. 
418 In the field, the incident wind is seldom perfectly perpendicular or normal to a scarp, so 419 Figure 13a illustrates wind speeds over a $2 \mathrm{~m}$ high scarp relative to wind speed $10 \mathrm{~m}$ above 420 the surface at the inlet of the computational domain for four incident wind directions, $90^{\circ}$

421 (perpendicular incident flow), $67.5^{\circ}, 45^{\circ}$ and $22.5^{\circ}$, and Figure $13 \mathrm{~b}$ illustrates the flow 422 velocity regions and streamlines for the four cases. 
a)

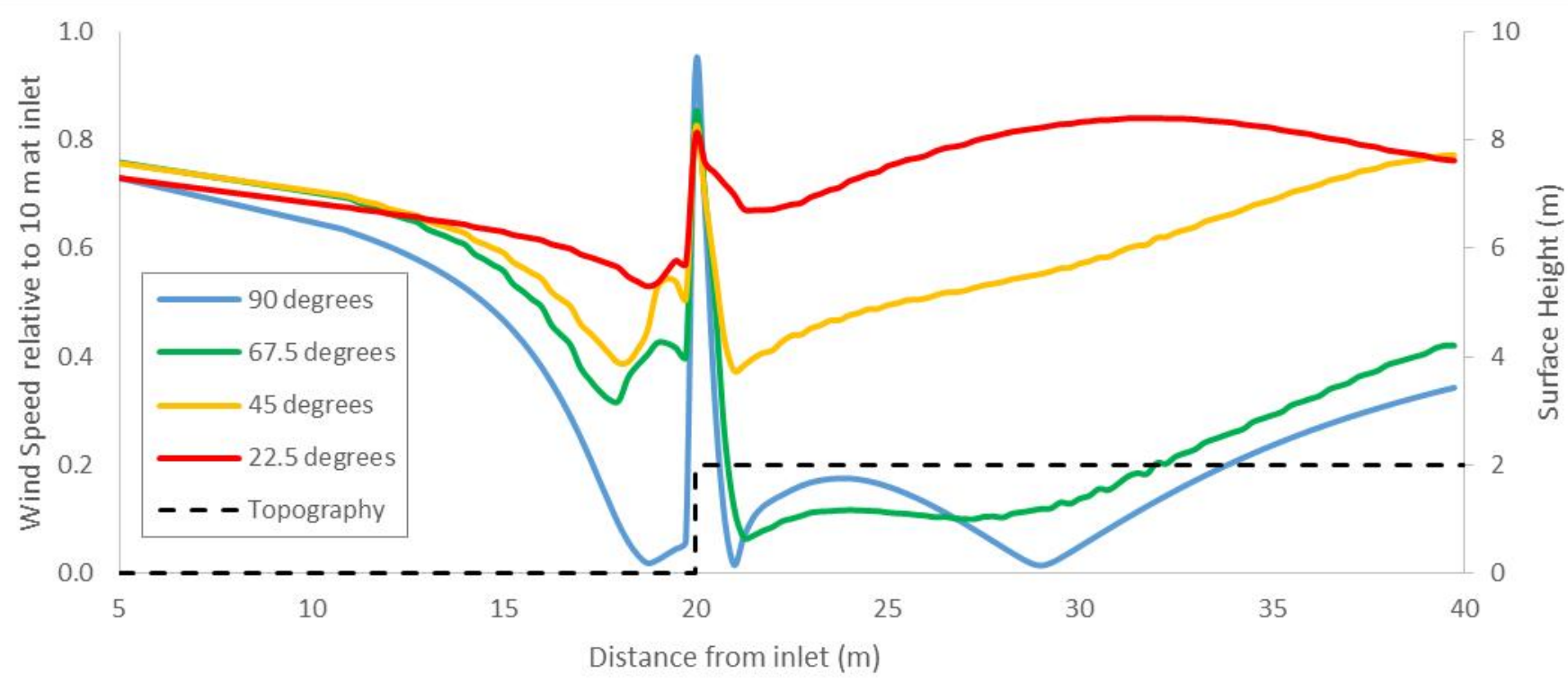

b)
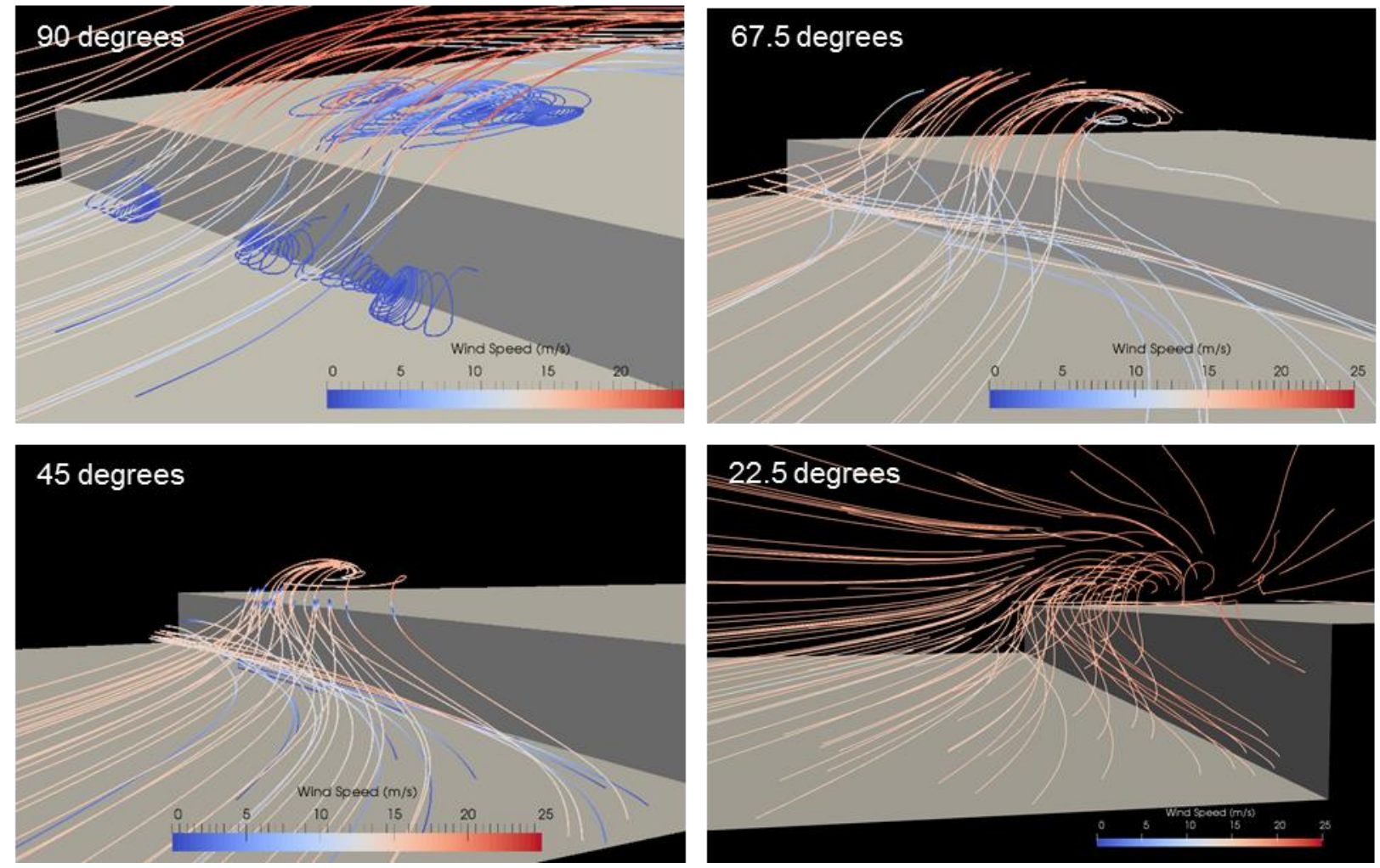

425 Figure 13. (a) Wind speed $0.25 \mathrm{~m}$ above the surface sampled every $0.25 \mathrm{~m}$ along a transect

426 perpendicular $\left(90^{\circ}\right)$, and at $67.5^{\circ}, 45^{\circ}$ and $22.5^{\circ}$ incident flow angles relative to the $2 \mathrm{~m}$ high

427 scarp. The highest speed reduction occurs at the base, and across the crest of the vertical 
scarp. As the incident wind becomes more oblique it undergoes a less significant reduction in speed at the toe of the scarp and in lee of the crest. (b) Streamlines seeded from a single point at the toe of the $2 \mathrm{~m}$ high scarp. 100 streamlines were seeded within a $5 \mathrm{~m}$ radius. When the incident wind is perpendicular to the crest, the wind flow becomes separated at the base forming vortices in a flow separation region. At $67.5^{\circ}, 45^{\circ}$, and $22.5^{\circ}$ some of the lower streamlines at the toe of the scarp are steered along the base of the scarp parallel to the scarp, and in the lee of the crest a helicoidal or corkscrew vortex is formed.

Wind flow is decelerated the most at the base of the scarp when wind flow is perpendicular to the scarp (Figure 13a). Figure $13 \mathrm{~b}$ (top left box $90^{\circ}$ ) shows that there is marked flow separation in the zone upwind of, and near the scarp base and a roller vortex is formed. As the wind becomes more oblique, it undergoes a less significant reduction in speed at the base of the scarp, and this effect becomes more pronounced as the incident wind obliquity increases such that there is roughly a $60 \%$ speed difference at the scarp base between the $90^{\circ}$ wind versus the $22.5^{\circ}$ wind. As noted above (e.g. Figure 11), the highest percent velocity occurs at the scarp crest for the $90^{\circ}$ incident flow and only marginally decreases with increasing incident wind obliquity.

Immediately downwind of the scarp, flow separation is pronounced for the $90^{\circ}$ and $67.5^{\circ}$ winds and the percent wind speed reduction is significant, falling to $0.01(1 \%)$ and $0.07(7 \%)$ respectively. The lowermost streamlines are topographically steered along-scarp for each of the oblique incident winds, and this effect increases with increasing obliquity (Figure 13b), as also observed in the field (Piscioneri et al., 2019). However, in all cases the flow flips over the crest and helicoidal or corkscrew vortices are common in the downwind crest region. When the incident wind flow direction is $22.5^{\circ}$ to the scarp, the flow undergoes the least 
wind speed reduction downwind of the crest. Similar results are observed for oblique flow over non-scarped foredunes (Hesp et al., 2015); at lower incident wind approach angles, there is less speedup, less flow deflection occurs, and a greater degree of along-dune topographic steering takes place.

\section{Discussion and Conclusions}

The perpendicular and oblique wind flow over a vertical scarp of varying heights and three slopes has been modelled utilising Computational Fluid Dynamics, and the results compare well with field and wind tunnel studies of flow over scarps (e.g. Hsu, 1977; Bowen and Lindley, 1977; Moriniere, 2007; Hesp et al., 2015; Piscioneri et al., 2019), and field studies of flow over unvegetated slopes (e.g. Inman et al., 1966; Mulligan, 1988; Hesp et al., 1989; Wiggs et al., 1996; Walker and Nickling, 2002; Parsons et al., 2004; Qian et al., 2009; Liu et al., 2011; Bruno and Fransos, 2015; Smyth and Hesp, 2015) . This study advances previous knowledge on scarps, slopes and forward facing steps in particular by analysing in more detail the variations in flow due to variations in scarp height and incident wind approach angles. In many cases, vegetation is variously present on scarp-fill slopes and may range from nebkha fields (Figure 14) to nearly complete cover depending on the stage of scarp fill recovery. The presence of vegetation, and slump blocks will naturally alter the near-surface flow field considerably.

In terms of relevance to dune formation following scarping and scarp fill processes, the formation of a separation region in front of a scarp will likely lead to the formation of an echo dune as shown, for example, by Tsoar (1983) and Carter et al. (1990), and this may be formed in both perpendicular incident flows where stationary roller vortices are formed, and in low to moderate angle oblique incident flows where corkscrew or helicoidal vortices occur (Hesp and Smyth, 2019). Topographically forced accelerations are significant where the 
476 slope is steep or where the scarp is vertical. The incident wind may be below threshold at the 477 beach or on the toe of the slope, but significantly higher flow velocities occur further upslope 478 leading to sometimes significant transport even when the regional wind is below threshold.

479 This topographically forced flow, particularly near the scarp/slope crest can induce sand 480 transport off the scarp wall (where the scarp is composed of sand), and transport grains in 481 suspension from locations below the scarp as has been observed in the field. Figure 14a 482 illustrates an example where sand is being transported up and over a vertical scarp wall by this process. Jet flow would act to increase transport up and over scarps and steep slopes, and downwind beyond the scarp/slope crest. Jets will enhance suspension of sand grains also.

485 Once the scarp fill ramp is formed, and particularly where slopes are lower than $\sim 50^{\circ}$, 486 topographic acceleration would lead to enhanced transport upslope and the more common 487 formation of dunes beyond the scarp crest (formingcliff-top dunes) in the flow separation region formed across, and downwind of the scarp crest (Figure 14b). The downwind length of the separation region is shown to be controlled by scarp height and wind velocity, and these will therefore affect the dimensions of the cliff top dunes as they form. 

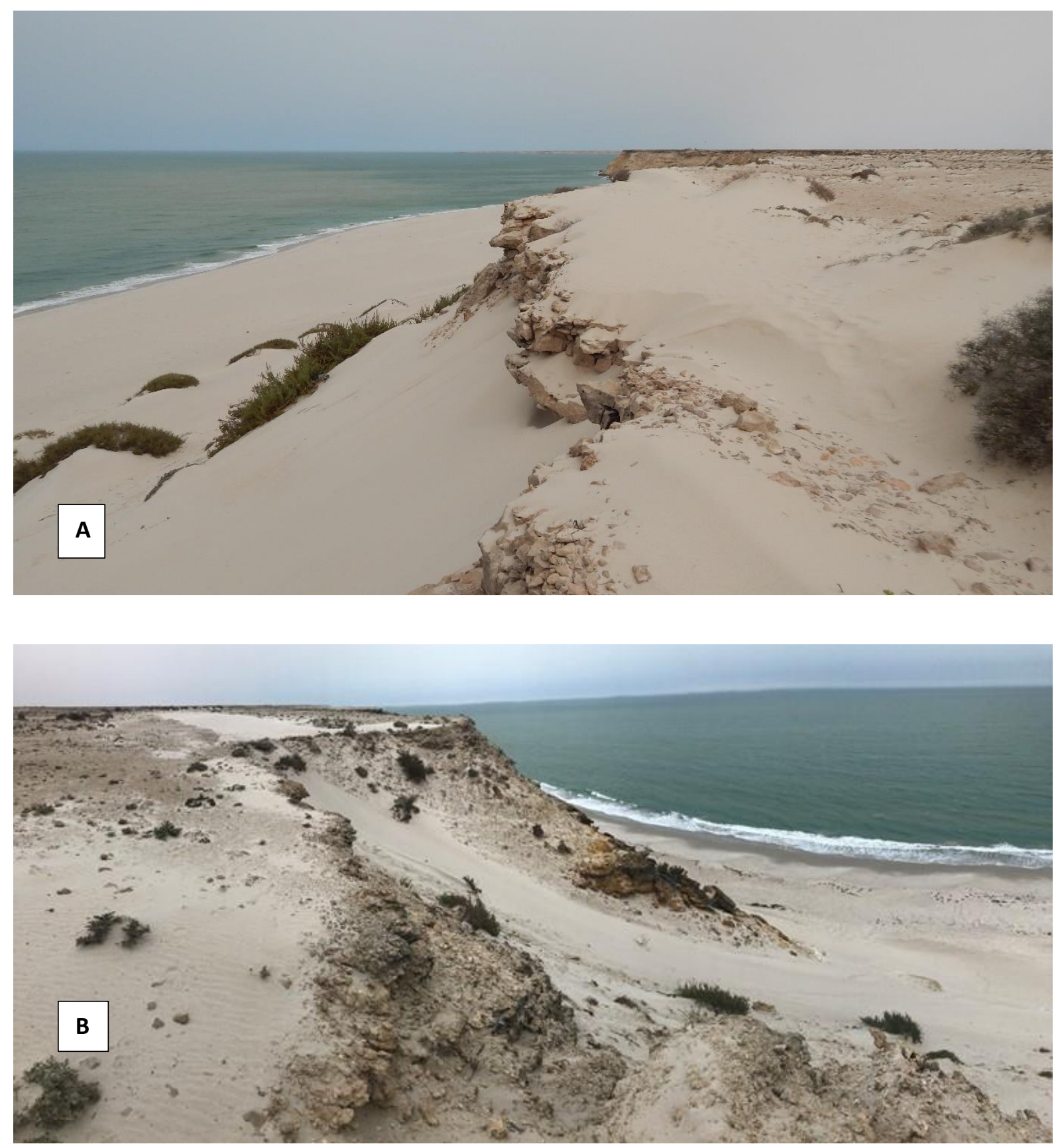

494 Figure 14. (A) Scarp or cliff top dunes forming in the flow separation region immediately downwind of a vertical scarp. (B) Climbing and clifftop dune system. The uppermost climbing dune slope was at an angle of $44^{\circ}$. Both examples, $80 \mathrm{~km}$ south of Dakhla, W. Sahara.

We anticipate these findings will aid in further understanding scarp and slope flow dynamics, and inform numerical and conceptual modelling of the transfer of sediment between beach 
and dune systems after a storm event and following scarp fill or ramp development and dune recovery.

The following conclusions may be made:

1. The flow structure upwind of the scarp and slopes examined varies according to slope gradient as found in previous studies. The zone of upwind flow deceleration is least for the lowest slope and increases with slope gradient, becoming pronounced for the vertical scarp.

2. There is marked flow separation in the zone upwind of, and near the vertical scarp base for the scarps higher than $1 \mathrm{~m}$.

3. Wind speed at the crest of scarps and slopes with equal height but differing slope reach a similar maximum. However, the zone of streamwise high speed flow extends further downwind beyond the scarp/slope crest as slope increases (becomes steeper). The highest flow velocity zone also occurs higher above the vertical scarp crest as a result of the topographically forced acceleration, and the turbulent shear layer existing above the flow separation region formed immediately at and downwind of the scarp crest.

4. The downwind extent and vertical depth of the crest flow separation region is greatest in the case of the vertical scarp and dramatically less once the slopes are at, or below $45^{\circ}$.

5. No flow separation is apparent at the base of the slopes, or downwind of the crest for the lower slopes $\left(45^{\circ}\right.$ and less $)$ for perpendicular winds.

6. Jets occur at the crests of the $45^{\circ}$, and $27^{\circ}$ slopes, and are even apparent at a slope of $14^{\circ}$. A jet is also highly likely to form at a vertical scarp as witnessed in various field studies. 
7. The vertical and horizontal extent of flow separation downwind of the scarp increases with scarp height, and the flow structure varies considerably as a function of scarp height.

8. As scarp height increases, the pressure upwind of the scarp increases, and the zone of high pressure extends further upwind. The zone of low pressure downwind of the scarp also extends further with an increase in scarp height.

9. The greatest wind flow deceleration occurs at the scarp base when wind flow is perpendicular $\left(90^{\circ}\right)$ to the scarp. As the incident wind becomes progressively more oblique, it undergoes a less significant reduction in speed at the base of the scarp such that there is roughly a $60 \%$ speed difference at the scarp base between a $90^{\circ}$ incident wind versus a $22.5^{\circ}$ incident wind.

\section{Acknowledgements}

Thanks to Flinders University and the BEADS Lab for supporting us and for a postdoctoral position for TS, and to Æolus for his continued ministry.

\section{References}

Abu-Mulaweh, H.I., 2005. Turbulent mixed convection flow over a forward-facing step-the effect of step heights. International Journal of Thermal Sciences 44 (2), 155-162.

Arens, S.M., Van Kaam-Peters, H.M.E., Van Boxel, J.H., 1995. Air flow over foredunes and implications for sand transport. Earth Surface Processes and Landforms 20 (4), 315-332.

Bagnold, R.A., 1954. The Physics of Blown Sand, Methuen, London, 265pp. 
Bauer, B.O., Walker, I.J., Baas, A.C.W., Jackson, D.W.T., Mckenna-Neuman, C.,

546 Wiggs, G.F.S., and Hesp, P.A., 2013. Critical Reflections on the Coherent Flow

547 Structures Paradigm in Aeolian Geomorphology. In: Venditti, J.G., Best, JL, Church,

548 M., Hardy, R.J. Eds. Coherent Flow Structures at the Earth's Surface. Wiley-

549 Blackwell, 111-134.

550 Billingsley, G.H., 1987. Geology and geomorphology of the southwestern Moenkopi Plateau

551 and southern Ward Terrace, Arizona. No. 1672. US Geological Survey.

552 Blocken, B., Stathopoulous, T., Carmeliet, J., 2007. CFD simulation of the atmospheric boundary layer: wall function problems. Atmospheric Environment, 41, 238-252.

554

555

Bourke, M., Bullard, J.E., Barnouin-Jha, O.S., 2004. Aeolian sediment transport pathways 556 and aerodynamics at troughs on Mars. Journal of Geophysical Research: Planets 109.E7.

557 Bowen, A.J., Lindley, D., 1977. A wind-tunnel investigation of the wind speed and 558 turbulence characteristics close to the ground over various escarpment shapes, Boundary559 Layer Meteorology 12, 259-271.

560 Brothers, R.N., 1954. A physiographic study of recent sand dunes on the Auckland west 561 coast. NZ Geographer 10, 47-59.

562 Bullard, J.E., Nash, D.J., 2000. Valley-marginal sand dunes in the south-west Kalahari: their 563 nature, classification and possible origins. J. Arid Environments 45 (4), 369-383.

564 Calliari, L.J., Pereira da Silva, R., 1998. Erosion Processes associated to storm surge and 565 washout along the southern Brazilian coastline. Journal of Coastal Research 26, 1-7. 
566 Carter, R.W.G., Hesp, P.A., Nordstrom, K., 1990. Geomorphology of erosional dune

567 landscapes. In: Nordstrom K, Psuty N, Carter RWG (Editors), Coastal Dunes: Processes and

568 Morphology, 217-250. J. Wiley and Sons.

569 Carter, R.W.G., Stone, G.W. 1989. Mechanisms associated with the erosion of sand dune

570 cliffs, Magilligan, Northern Ireland. Earth Surface Processes and Landforms 14 (1), 1-10.

571 Castelle, B., Marieu, V., Bujan, S., Splinter, K. D., Robinet, A., Sénéchal, N., Ferreira, S.,

572 2015. Impact of the winter 2013-2014 series of severe Western Europe storms on a double-

573 barred sandy coast: Beach and dune erosion and megacusp embayments. Geomorphology,

$574238,135-148$.

575 Christensen, M.B., 2003. Effects of dune ramps on sediment supply to coastal foredunes:

576 Skallingen, SW Denmark. Proceedings Coastal Sediments '03, East Meets West Productions,

577 Corpus Christi, p.14.

578 Christiansen, M. B., \& Davidson-Arnott, R., 2004. Rates of landward sand transport over the 579 foredune at Skallingen, Denmark and the role of dune ramps. Geografisk Tidsskrift-Danish 580 Journal of Geography, 104(1), 31-43.

581 Chou Jung-Hua, Chao, S.Y., 2000. Branching of a horseshoe vortex around surface-mounted 582 rectangular cylinders. Experiments in Fluids 28 (5), 394-402.

583 Clemmensen, L.B.., Fornós, J.J., Rodriguez-Perea, A., 1997. Morphology and architecture of 584 a late Pleistocene cliff-front dune, Mallorca, Western Mediterranean. Terra Nova 9 (5-6), $585 \quad 251-254$.

586 Cooke, R.U., Warren, A., Goudie, A.S., 1993. Desert Geomorphology. UCL Press, London. $587 \quad 526 \mathrm{pp}$. 
Davidson-Arnott, R., 2005. Conceptual model of the effects of sea level rise on sandy coasts.

590 Davidson-Arnott, R.G.D., Hesp, P.A., Ollerhead, J.O., Walker, I.J., Bauer, B.O., Delgado-

591 Fernandez, I, Smyth, T.A.G., 2018. Sediment Budget Controls on Foredune Height: a

592 Comparison of Simulation Model Results and Field Data. Earth Surface Processes \& 593 Landforms 43(9), 1798-1810. (http://dx.doi.org/10.1002/esp.4354).

594 Elkhoury, M., 2016. Assessment of turbulence models for the simulation of turbulent flows 595 past bluff bodies. J. Wind Engineering and Industrial Aerodynamics 154, 10-20.

596 Emeis, S., Frank, H.P., Fiedler, F., 1995. Modification of air flow over an escarpment597 results from the Hjardemål experiment. Boundary-Layer Meteorology 74 (1-2), 131-161.

598 Evans, J.R., 1962. Falling and climbing sand dunes in Cronese "Cat" Mountains, San 599 Bernardino County, California. J. Geology 70, 107-113.

600 Hack, J.T., 1941. Dunes of the Western Navajo Country. Geographical Review 31 (2), 240601263.

602

Hattori, H., Nagano, Y., 2010. Investigation of turbulent boundary layer flow over forward 603 facing step via direct numerical simulation. Intl. J. Heat and Fluid Flow 31 (3), 284-294.

604 Hesp, P.A., 2002. Foredunes and Blowouts: initiation, geomorphology and dynamics. 605 Geomorphology 48, 245-268.

606 Hesp, P.A., 2005. Flow reversal and dynamics of foredunes and climbing dunes on a 607 leeward east coast, New Zealand. Zeit fur Geomorphologie Supple. 141 Coasts Under 608 Stress II Psuty N.P., Sherman D.J., Meyer-Arendt K. [Editors], 123-134. 
Hesp, P.A., Illenberger, W., Rust, I., A. McLachlan, A., Hyde, R., 1989; Some aspects of transgressive dunefield and transverse dune geomorphology and dynamics, south coast, South Africa. Zeitschrift fur Geomorph. Suppl-Bd 73, 111-123.

Hesp, P.A., Smyth, T.A.G., Nielsen, P., Walker, I.J., Bauer, B.O., Davidson-Arnott, R.G., 2015. Flow deflection over a foredune. Geomorphology 230, 64-74.

Hesp, P.A., Smyth, T.A.G., 2016. Jet flow over foredunes. Earth Surface Processes and Landforms 41: 1727-1735. DOI: 10.1002/esp.3945

Hesp, P.A., Smyth, T.A.G., 2019. Anchored Dunes. In: I. Livingstone and A. Warren (Eds.), Aeolian Geomorphology: a New Introduction: 157-178. Wiley Blackwell.

Hesp, P.A., Smyth, T.A.G., Nielsen, P., Walker, I.J., Bauer, B.O., Davidson-Arnott, R., 2015. Flow deflection over a foredune. Geomorphology 230, 64-74.

Hesp, P.A., Walker, I.J., 2013. Aeolian environments: coastal dunes. In: Shroder J. Editor in Chief, Lancaster N, Sherman DJ, Baas ACW Eds., Treatise on Geomorphology, vol. 11, Aeolian Geomorphology. Academic Press, San Diego, CA, 109-133.

Hesp, P.A., Walker, I.J., Namikas, S.L., Davidson-Arnott, R., Bauer, B.O., Ollerhead, J., 2009. Storm wind flow over a foredune, Prince Edward Island, Canada. J. Coastal Research SI 56, 312-316.

Hesp, P.A., Walker, I.J., Chapman, C., Davidson-Arnott, R., Bauer, B.O., 2013. Aeolian dynamics over a coastal foredune, Prince Edward Island, Canada, Earth Surface Processes and Landforms 38 (1), 1566-1575.

Hilton, M.J., Hatcher, S.V., Wakes, S.J., Konlechner, T.M., 2016. Flow deflection and deceleration across a simple foredune. Journal of Coastal Research 75 (sp1), 293-298. 
631 Hsu, S.A. 1977. Boundary-layer meteorological research in the coastal zone. Geoscience and 632 Man XVIII, 99-111.

633

Hucho, W.H., Sovran, G., 1993. Aerodynamics of road vehicles. Annual Review Fluid 634 Mechanics 25 (1), 485-537.

Jackson, D.W. T., Beyers, J. H. M., Lynch, K., Cooper, J. A. G., Baas, A. C. W., \& Delgado636 Fernandez, 2011. Investigation of three-dimensional wind flow behaviour over coastal dune morphology under offshore winds using computational fluid dynamics (CFD) and ultrasonic anemometry. Earth Surface Processes and Landforms, 36, (8), 1113-1124.

639

640

Jarmalavicius, D., Satkunas, J., Zilinskas, G., Pupienis, D., 2012. The influence of coastal

641 morphology on wind dynamics. Estonian J. Earth Science 61 (2), 120-130.

642

Karunarathna, H., Brown, J., Chatzirodou, A., Dissanayake, P., Wisse, P., 2018. Multitimescale morphological modelling of a dune-fronted sandy beach. Coastal Engineering 136, 161-171.

Kim, H.G., Lee, C.M., Lim, H.C., Kyong, N.H., 1997. An experimental and numerical study on the flow over two-dimensional hills. J. Wind Eng. Ind. Aerodyn. 66, 17-33.

647 Kim, H.G., Patel, V.C., Lee, M.L., 2000. Numerical simulation of wind flow over hilly 648 terrain. J. Wind Eng. Ind. Aerodyn. 87, 45-60.

649 Kourta, A., Thacker, A., Joussot, R., 2015. Analysis and characterization of ramp flow 650 separation. Experiments in Fluids:56 (5), 1-14.

651 Lancaster, N., Tchakerian, V.P., 1996. Geomorphology and sediments of sand ramps in the 652 Mojave Desert. Geomorphology 17 (1), 151-165. 
653

654

655

656

657

658

659

660

661

662

663

664

665

666

667

668

669

670

671

672

673

674

675

676

Largeau, J.F., Moriniere, V., 2007. Wall pressure fluctuations and topology in separated flows over a forward-facing step. Exp. Fluids 42, 21-40.

Lesieur, M., Begou, P., Briand, E., Danet, A., Delcayre, F., Aider, J.L., 2003. Coherentvortex dynamics in large-eddy simulations of turbulence. J. of Turbulence 4, N16.

Liu, B., Qu, J., Zhang, W., Qian, G., 2011. Numerical simulation of wind flow over transverse and pyramid dunes. Journal of Wind Engineering and Industrial Aerodynamics, 99(8), 879-888.

Lorenz, R.D., Zimbelman, J.R., 2014. Other dunes and other sand deposits, In: Lorenz RD, Zimbelman, J.R., Dune Worlds: How Windblown Sand Shapes Planetary Landscapes, 93102. Springer Praxis Books.

Masselink, G., Castelle, B., Scott, T., Dodet, G., Suanez, S., Jackson, D., Floc'h, F., 2016. Extreme wave activity during 2013/2014 winter and morphological impacts along the Atlantic coast of Europe. Geophysical Research Letters, 43(5), 2135-2143.

Maurizi, A., 2000. Numerical simulation of turbulent flows over 2-D valleys using three versions of the kappa-epsilon closure model. J. Wind Eng. Ind. Aerodyn. 85 (1), 59-73

Mazumder, B.S., Sarkar, K., 2014. Turbulent flow characteristics and drag over 2-D forwardfacing dune shaped structures with two different stoss-side slopes. Environmental Fluid Mechanics 14, 617-645.

Mulligan, K. R., 1988. Velocity profiles measured on the windward slope of a transverse dune. Earth Surface Processes and Landforms, 13(7), 573-582.

Ollerhead, J., Davidson-Arnott, R., Walker, I. J., Mathew, S., 2013. Annual to decadal morphodynamics of the foredune system at Greenwich Dunes, Prince Edward Island, Canada. Earth Surface Processes and Landforms, 38(3), 284-298. 
678 Parsons, D.R., Walker, I.J., Wiggs, G.F.S., 2004. Numerical modelling of flow structures 679 over idealized transverse aeolian dunes of varying geometry. Geomorphology 59 (1), 149680164

681 Patankar, S.V., Spalding, D.B., 1972. A calculation procedure for heat, mass and momentum 682 transfer in three-dimensional parabolic flows. International Journal of Heat and Mass 683 Transfer $15(10), 1787-1806$.

684 Pearson, D.S., Goulart, P.J., Ganapathisubramani, B., 2013. Turbulent separation upstream of 685 a forward-facing step. Journal of Fluid Mechanics 724, 284-304.

686 Pires, L., de Souza, L.F., Fisch, G., Gielow, R., 2011. Numerical study of the atmospheric 687 flow over a coastal cliff. International Journal for Numerical Methods in Fluids 67 (5), 599688608.

689 Pires, L.B., Fisch, G., Gielow, R., Souza, L.F., Avelar, A.C., De Paula, I.B., Girardi, R.D., 690 2015. A study of the internal Boundary layer generated at the Alcantara Space Center. 691 American Journal of Environmental Engineering 5 1A, 52-64.

692 Piscioneri, N., Smyth, T.A.G., Hesp, P.A., 2019. Flow dynamics over a foredune scarp. Earth 693 Surface Processes and Landforms 44(5), 1064-1076.

694 Prandtl, L., 1904. Uber Flussigkeits bewegung bei sehr kleiner Reibung, Verhaldlg III Int. 695 Math. Kong. Heidelberg: Teubner, 484-491; Also available in translation as: Motion of 696 fluids with very little viscosity, NACA TM 452, March 1928.

697 Pye, K., Tsoar, H., 1990. Aeolian Sand and Sand Deposits. Springer Science \& Business 698 Media, 396pp. 
699

700

701

702

703

704

705

706

707

708

709

710

711

712

713

714

715

716

717

718

719

720

Qian, G., Dong, Z., Luo, W., Lu, J., 2011. Mean airflow patterns upwind of topographic obstacles and their implications for the formation of echo dunes: A wind tunnel simulation of the effects of windward slope. Journal of Geophysical Research: Earth Surface, 116 F4 .

Qian, G., Dong, Z., Luo, W., Wang, H., 2009. Variations of horizontal and vertical velocities over two-dimensional transverse dunes: A wind tunnel simulation of the effect of windward slope. Journal of Arid Environments, 73(12), 1109-1116.

Qian, G., Dong, Z., Luo, W., Zhang, Z., Zhao, A., 2012. Airflow patterns upwind of obstacles and their significance for echo dune formation: A field measurement of the effects of the windward slope angle. Science China Earth Sciences 55 (4), 545-53.

Richards, P.J., Hoxey, R.P., 1993. Appropriate boundary conditions for computational wind engineering models using the $\mathrm{k}-\epsilon$ turbulence model. Journal of wind engineering and industrial aerodynamics 46, 145-153.

Robin, N., Billy, J., Castelle, B., Hesp, P.A., Laporte-Fauret, Q., Lerma, N.A., Marieu, V., Rosebery, D., Bujan, S., Destribats, B., and Michalet, R., 2020. Beach-dune recovery from the extreme 2013-2014 at Truc Vert Beach, Southwest France: New insights from GroundPenetrating Radar. J. Coastal Research SI 95: 1-5.

Rowcroft, J., Burton, D., Blackburn, H.M., Sheridan, J., 2015. Siting wind turbines near cliffs - the effect of wind direction. Wind Energy 19(8), 1469-1484.

Shao, W., Agelin-Chaab, M., 2016. Turbulent Flows Over Forward Facing Steps With Surface Roughness. Journal of Fluids Engineering, 138(2), 021103. 

recirculation zone formed downstream of a forward facing step. Journal of Wind Engineering and Industrial Aerodynamics, 98(12), 888-894.

724 Smyth, T. A., 2016. A review of Computational Fluid Dynamics (CFD) airflow modelling over aeolian landforms. Aeolian Research, 22, 153-164.

726

Smyth, T.A.G., Hesp, P.A., 2015. Aeolian dynamics of beach scraped dunes. Coastal Engineering 99, 38-45.

Smyth, T.A.G., Jackson, D.W.T., Cooper, J.A.G., 2012. High resolution measured and modelled three-dimensional airflow over a coastal bowl blowout, Geomorphology 177-178, $62-73$.

Smyth, T.A.G., Jackson, D.W.T., Cooper, J.A.G., 2013. Three dimensional airflow patterns within a coastal trough - bowl blowout during fresh breeze to hurricane force winds. Aeolian Research 9, 111-123.

Song, S., Eaton, J.K., 2004. Flow structures of a separating, reattaching and recovering boundary layer for a large range of Reynolds number. Exp. Fluids 36 (4), 642-653. after storm erosion on a high-energy beach: Vougot Beach, Brittany (France).

740 Geomorphology 139, 16-33.

741 Tsoar, H., 1983. Wind tunnel modelling of echo and climbing dunes. Developments in 742 Sedimentology 38, 247-259. 
Tsoar, H., Blumberg, D., 1991. The effect of sea cliffs on inland encroachment of aeolian sand. In: Barndorff-Nielsen O, Willetts BB Eds. Aeolian Grain Transport 2 The Erosional Environment. Acta Mechanica Suppl 2, 131-146.

Tsoar, H., White, B., Berman, E., 1996. The effect of slopes on sand transport - numerical modelling. Landscape and Urban Planning 34 (3-4), 171-181.

van der Kindere, J., Ganapathisubramani, B., 2018. Effect of length of two-dimensional obstacles on characteristics of separation and reattachment. Journal of Wind Engineering and Industrial Aerodynamics 178, 38-48

Uruba, V., Knob, M., 2009. Dynamics of a boundary layer separation. Engineering Mechanics $16(1), 29-38$.

Walker, I. J., Davidson-Arnott, R. G., Bauer, B. O., Hesp, P. A., Delgado-Fernandez, I., Ollerhead, J., Smyth, T. A., 2017. Scale-dependent perspectives on the geomorphology and evolution of beach-dune systems. Earth-Science Reviews, 171, 220-253.

Walker, I. J., Nickling, W. G. (2002). Dynamics of secondary airflow and sediment transport over and in the lee of transverse dunes. Progress in Physical Geography, 26(1), 47-75.

Wiggs , G.F.S., Bullard, J.E., Garvey, B., Castro, I., 2002. Interactions Between Airflow and Valley Topography with Implications for Aeolian Sediment Transport, Physical Geography, 23:5, 366-380, DOI: 10.2747/0272-3646.23.5.366

Wiggs, G. F., Livingstone, I., Warren, A., 1996. The role of streamline curvature in sand dune dynamics: evidence from field and wind tunnel measurements. Geomorphology, 17(13), 29-46. 
766 Xianwan, L., Sen, L., Jianyou, S., 1999. Wind tunnel simulation experiment of mountain

767 dunes. Journal of Arid Environments;42 (1), 49-59.

768 Yassin, M.F., Al-Harbi, M., 2013. Numerical simulation on wind flow over step-shaped cliff 769 topography with rough surface. Int. J. Environ.Res. 7 (1), 173-186. 